\title{
PHRENOLOGY, CORRESPONDENCE, AND THE GLOBAL POLITICS OF REFORM, 1815-1848*
}

\author{
JAMES POSKETT \\ University of Cambridge
}

\begin{abstract}
Like many nineteenth-century sciences, phrenology had global aspirations. Skulls were collected in Egypt and Ceylon, societies exchanged journals between India and the United States, and phrenological bestsellers were sold in Shanghai and Tokyo. Despite this wealth of interaction, existing accounts treat phrenology within neat national and urban settings. In contrast, this article examines phrenology as a global political project. During an age in which character dominated public discourse, phrenology emerged as a powerful political language. In this article, I examine the role that correspondence played in establishing material connections between phrenologists and their political concerns, ranging from the abolition of slavery to the reform of prison discipline. Two overarching arguments run throughout my case studies. First, phrenologists used correspondence to establish reform as a global project. Second, phrenology allowed reformers to present their arguments in terms of a new understanding of human character. More broadly, this article connects political thought with the global history of science.
\end{abstract}

The following text is an open-access copy of the original manuscript. For the typeset edition, please consult The Historical Journal website: http://journals.cambridge.org/action/displayJournal?jid=HIS

What was the most important reform of the nineteenth century? For Orson Fowler, editor of The American Phrenological Journal in New York City, it was the penny post. In an article calling on the United States to adopt a similar system to the one established in Britain in 1840 , Fowler argued that 'probably no reform of modern times compares with this in its destined utility'. For the American phrenologist, all other reforms - from new prison systems to the abolition of slavery - relied on 'communion on paper'. The penny post would 'promote mental discipline, and the public good'. It would 'bind man to man in one common 
brotherhood'. 'This vision of reform was grounded in a new understanding of human nature, one that rejected earlier traditions of moral philosophy. For phrenologists, the mind was material, with distinct areas of the brain devoted to intellectual, moral and animal faculties. Fowler explained that 'every letter, every paper, and book, becomes a teacher of some kind, and exercises, and thereby develops the mind of both producer and reader'. ${ }^{2}$ Phrenologists on the other side of the Atlantic were equally enthusiastic about correspondence. Hewett Watson, editor of The Phrenological Journal in Edinburgh, also championed 'Cheap Postage', writing 'the free interchange of ideas... tends most powerfully to promote the moral improvement of mankind' ${ }^{3}$ Rowland Hill, the pioneer of the Uniform Penny Post in Britain, was even subject to a phrenological analysis. The significance of Hill's reform was matched to a protruding forehead, illustrating a 'general intellect of a very high order'.

Picking up on the phrenologists' concern with correspondence and the politics of the mind, this article explores the use of letters in three major nineteenth-century reform debates: the abolition of slavery, prison discipline, and education. In doing so, this article develops two overarching arguments. First, phrenologists used correspondence to establish reform as a global project. Second, phrenology allowed reformers to present their arguments in terms of a new understanding of human character.

Phrenology is a particularly productive discipline through which to re-examine the relationship between science and politics in the context of global history. ${ }^{5}$ Throughout the

Darwin College, University of Cambridge, Silver Street, Cambridge, CB3 9EU, UK, jdgp2@cam.ac.uk

* Janet Browne, Simon Schaffer, Jim Secord, Sujit Sivasundaram, Alice Poskett and three anonymous referees all provided invaluable feedback on earlier drafts of this article. I would like to thank the Master and Fellows of both Trinity College and Darwin College at the University of Cambridge for supporting my research, first under the Tarner Studentship and then as the Adrian Research Fellow. The British Society for the History of Science and the Countway Library of Medicine at Harvard University provided additional funding for archival work in Scotland and the United States respectively, for which I am most grateful.

${ }^{1}$ O. Fowler, 'Cheap postage and friendly correspondence', The American Phrenological Journal, 10 (1848), p. 27. On the campaign and development of the penny post in the United States, see F. Staff, The penny post, 1680-1918 (London, 1964), pp. 96-104.

${ }^{2}$ O. Fowler, 'Excellent post-office suggestion', The American Phrenological Journal, 11 (1849), pp. 36-8.

${ }^{3}$ H. Watson, 'Cheap postage', The Phrenological Journal, 11 (1838), p. 72.

${ }^{4}$ F. Bridges, Phrenology made practical and popularly explained (London, 1857), pp. 160-1.

${ }^{5}$ On the move towards global histories of science, see S. Sivasundaram, 'Sciences and the global: on methods, questions, and theory', Isis, 101 (2010), pp. 146-58. 
Napoleonic Wars, the German physician Franz Joseph Gall travelled across Continental Europe, presenting his craniological principles to audiences in Berlin, Copenhagen and Amsterdam. In 1828, Gall died in Paris - his 'doctrine of the skull' had not travelled far. ${ }^{6}$ But by the middle of the nineteenth century, phrenologists were self-consciously promoting their work as part of a global scientific movement. Skulls were collected in China and Africa, societies cross-circulated journals between Edinburgh and Calcutta, and translations of French phrenological works were imported into Melbourne and Boston. Phrenological books were the international bestsellers of the day. In 1828 George Combe, a Scottish lawyer and President of the Edinburgh Phrenological Society, published an unassuming duodecimo entitled The constitution of man. ${ }^{7}$ Over the course of the nineteenth century, this book sold far more copies than Charles Darwin's On the origin of species. ${ }^{8}$ Combe's work was translated into at least six languages, including Bengali and Japanese, and found readers in cities ranging from New York to Shanghai. ${ }^{9}$ Despite all this, historians have yet to address phrenology's global aspirations and continue to treat it within formulaic national contexts, from the July Monarchy in France to the Reform Act in Britain. ${ }^{10}$ In contrast, this article considers phrenology as a global science and, in doing so, seeks to reconnect the history of science with political and social history. ${ }^{11}$

\footnotetext{
${ }^{6}$ J. van Wyhe, 'The authority of human nature: the Schädellehre of Franz Joseph Gall', The British Journal for
} the History of Science, 35 (2002), pp. 17-42.

${ }^{7}$ For the history of The constitution of man in Britain see J. Secord, Visions of science: books and readers at the dawn of the Victorian age (Oxford, 2014), pp. 173-204 and J. van Wyhe, Phrenology and the origins of Victorian scientific naturalism (Aldershot, 2004), pp. 96-164.

${ }^{8}$ The constitution of man sold well over 300,000 copies by 1900. On the origin of species only managed 50,000, R. Cooter, The cultural meaning of popular science (Cambridge, 1984), p. 120.

${ }^{9}$ R. Das, Manatatwa sarsangraha (Calcutta, 1849), N. Hideki, Seisogaku genron (Tokyo, 1918) and P. Feng, Gu xiang xue (Shanghai, 1923). van Wyhe, Phrenology, pp. 217-28 lists editions in European languages including French, German and Swedish.

${ }^{10}$ Much of this work follows S. Shapin, 'Phrenological knowledge and the social Structure of early nineteenthcentury Edinburgh', Annals of Science, 32 (1975), pp. 219-43. For France, see M. Renneville, Le langage des crânes (Paris, 2000).

${ }^{11}$ For the growing body of work on the global history of reform and revolution see, D. Armitage and $\mathrm{S}$. Subrahmanyam, eds, The age of revolutions in global context, 1760-1840 (Basingstoke, 2010), C. Bayly, The birth of the modern world, 1780-1914: global connections and comparisons (Oxford, 2004), and T. Popkewitz, Rethinking the history of education: transnational perspectives on its questions, methods, and knowledge (Basingstoke, 2013). 
What previous historians have failed to appreciate is the direct link between the phrenologists' infatuation with a global movement and their philosophy of a material mind. ${ }^{12}$ For those working within eighteenth-century traditions of moral philosophy, the geography of mental science held no particular epistemological or political significance. Dugald Stewart, Professor of Moral Philosophy at the University of Edinburgh, could simply assume that all minds were governed by the same laws. But for the phrenologists, things were not so easy. If the mind was material, then what guaranteed that brains in India and America were subject to the same laws of nature? It was this question that led phrenologists to fixate on the material connections which bound their world together. For these nineteenth-century materialists, the global was also a guarantee of truth. Combe made this explicit when he challenged Thomas Stone, one of the foremost critics of phrenology in Edinburgh, to explain how a false science could have so quickly 'spread over Europe, and taken root in Asia and America'. According to Combe, 'nothing but the force of truth' could account for the emergence of phrenology as a global science. ${ }^{13}$ This viewpoint was not unique to Britain. The East India Company surgeon George Murray Paterson also explained how he had come to see the correctness of phrenology only after examining over 3,000 heads during his travels across the British empire. Paterson's 'very numerous manipulations in Europe, Southern Africa \& the vast continent of Asia' apparently proved that phrenology worked irrespective of place. ${ }^{14}$ In the nineteenth century, as today, global talk proved a powerful ideology. Nowhere was this more true than in the sciences of the mind.

What all this suggests is that historians need to distinguish between the global as an analytic category and the global as an actors' category. ${ }^{15}$ Whilst there is much discussion on the value and means of practising global history today, there is little reflection on the history

\footnotetext{
${ }^{12}$ For the history of the material mind in this period, see R. Young, Mind, brain and adaptation in the nineteenth century (Oxford, 1970), R. Smith, The Fontana history of the human sciences (London, 1997), pp. 407-20, and L. Jacyna, 'The physiology of mind, the unity of nature, and the moral order in Victorian thought', The British Journal for the History of Science, 14 (1981), pp. 109-32.

${ }^{13}$ G. Combe, 'Answer to Mr Stone's observations', The Phrenological Journal, 6 (1829-1830), pp. 1-14, at pp. $13-14$.

${ }^{14}$ Paterson to Combe, [May 1823], MS7211, f. 9, George Combe Papers, National Library of Scotland, UK (henceforth, 'Combe Papers').

${ }^{15}$ G. Eley, 'Historicizing the global, politicizing capital: giving the present a name', History Workshop Journal, 63 (2007), pp. 154-188 and S. Moyn and A. Sartori, 'Approaches to global intellectual history', in S. Moyn and A. Sartori, eds, Global intellectual history (New York City, NY, 2013), p. 5.
} 
of the global from the perspective of the past. ${ }^{16}$ As this article shows, the nineteenth century witnessed a proliferation of ways of thinking about the globe. Phrenologists certainly promoted a diffusionist narrative, but this was only one aspect of a much more complex picture. Phrenologists also treated their subject matter comparatively. Skulls were best considered 'in juxtaposition' according to Combe. That way phrenologists could discern 'the mental characters of the respective tribes', whether 'Hindoo', 'Charib', 'Negro' or 'American'. But phrenologists didn't just think comparatively. They also presented the globe as connected. This was an age of 'power-looms, rail-roads, steam-boats, and gas-lights'. The core argument of The constitution of man was that human nature could no longer be considered in isolation from an industrialising world. The mind needed to be studied 'in relation to external objects' ${ }^{17}$ In this article I therefore treat the global as an actors' category just as much as an analytic category. The relationship between the two is at the heart of how we should understand global history.

Phrenologists were not alone in adopting a range of approaches to thinking about the globe. During the same period in which phrenology rose to prominence, the French naturalist George Cuvier began to piece together the earth's geohistory through the fossil record. Cuvier advanced geology as a science which, in his words, "collects the monuments of the physical history of the globe' ${ }^{18}$ Other disciplines promoted their own visions of the material world. When the botanist Joseph Hooker arrived on Kerguelen's Land in 1840, he carefully noted that 'the Lichens appear here to form a greater comparative portion of the vegetable world than in any other portion of the globe'. These specimens later featured in the detailed classificatory system Hooker described in his Flora Antarctica.${ }^{19}$ Others presented the world as an essentially connected space. The Prussian explorer Alexander von Humboldt sought to comprehend 'the reciprocal interaction, the struggle, as it were, of the divided physical

\footnotetext{
${ }^{16}$ For a good cross-section of these debates, see the essays collected together in the special issue of History Workshop Journal, introduced by F. Driver, 'Global times and spaces: on historicizing the global', History Workshop Journal, 64 (2007), pp. 321-2.

${ }^{17}$ G. Combe, The constitution of man (Edinburgh, 1828), p. 145 and 254.

${ }^{18}$ M. Rudwick, Bursting the limits of time: the reconstruction of geohistory in the age of revolution (Chicago, IL, 2005), p. 363.

${ }^{19}$ J. Endersby, Imperial nature: Joseph Hooker and the practices of Victorian science (Chicago, IL, 2008), pp. 44-5.
} 
forces'. Humboldt called this 'physique du monde', or terrestrial physics. ${ }^{20}$ Still, there was something that set phrenology apart from these other sciences. Whilst geology and botany had always been concerned with the material world to some extent, the same was not true for mental philosophy. Phrenology provided a new materialist understanding of the mind, one to match the global age of reform and revolution.

The current historiography also raises serious questions about the relationship between science and politics more generally. Since the work of Steven Shapin and Roger Cooter, phrenology has been consistently linked to reform. ${ }^{21}$ However, more recent work has challenged this interpretation. John van Wyhe rightly points out just how heterogeneous even a national political context could be. In Britain, phrenology found supporters ranging from Tory churchmen like the Reverend Henry Wintle to radical leaders like the Chartist William Lovett, a man who read The constitution of man whilst serving time in Warwick Gaol. ${ }^{22}$ Given this diversity of political support, ranging from Tories to Chartists, van Wyhe concludes that 'phrenology was not, essentially, about reform'. ${ }^{23}$

There is, however, a serious flaw with van Wyhe's argument. It rests on an extremely narrow understanding of what constitutes political thought. The history of political thought does not rest on establishing one-to-one relationships between social contexts and political views. Instead, it uncovers how particular ideas - from liberalism to Marxism - are used in practice. Identical political language is often put to a variety of conflicting uses. ${ }^{24}$ The very word 'reform' is a case in point. In the nineteenth century, the meaning of the term ranged from moral correction to institutional restructuring. This period also saw the development of a 'reform programme'. Previously separate projects, such as the improvement of school and prison facilities, came to be linked. ${ }^{25}$ Most importantly, 'reform' did not denote a particular

\footnotetext{
${ }^{20}$ M. Dettelbach, 'Humboldtian science', in N. Jardine, J. Secord and E. Spary, eds, Cultures of natural history (Cambridge, 1996), pp. 288-9.

${ }^{21}$ Shapin, 'Phrenological knowledge', pp. 219-43 and Cooter, Cultural meaning, pp. 1-14.

${ }^{22}$ D.Stack, 'William Lovett and the National Association for the Political and Social Improvement of the People', The Historical Journal, 42 (1999), pp. 1027-50 and J. van Wyhe, 'Was phrenology a reform science? Towards a new generalization for phrenology', History of Science, 42 (2004), pp. 313-31, at p. 315.

${ }^{23}$ Wyhe, 'Was phrenology a reform science?', p. 326.

${ }^{24}$ G. Jones, Languages of class: studies in English working class history, 1832-1982 (Cambridge, 1983), pp. 90178.

${ }^{25}$ J. Innes, 'Reform' in English public life: the fortunes of a word', in A. Burns and J. Innes, eds, Rethinking the age of reform: Britain 1780-1850 (Cambridge, 2003), pp. 71-97.
} 
party politics. Whigs, Tories, Owenites and Chartists all presented themselves as 'reformers' when it suited them, particularly after $1832 .{ }^{26}$ van Wyhe therefore wrongly assumes that political diversity undermines Shapin and Cooter's identification of phrenology with reform. And just as the language of reform could be put to diverse ends, so could the sciences.$^{27}$ In this case, the historical work is precisely to uncover how phrenology could be adopted by both British abolitionists and American slaveholders. In this article I treat reform as it was in the nineteenth century, as something open to contestation and appropriation. In doing so, I reestablish phrenology as a reform science.

The global scale is an important part of my argument. By following letters across traditional political geographies, we get a clearer sense of how historical actors deployed phrenology when confronted with both complementary and conflicting moral worlds. Often this tension was resolved by imagining local reform as part of a global project. So despite the obvious social, environmental and political differences between prison colonies in the Pacific and American penitentiaries, phrenologists separated by thousands of miles came to conceive of the two as part of the same scheme. It is only by looking at letter-writing as a material practice that we can fully understand how phrenology could be deployed over such an incredible range of geographies and put to such diverse political ends. Letters were above all material objects - pieces of paper, inscribed with ink, folded, stamped with wax, and transported by runners, mail-coaches and steamships. ${ }^{28}$ Nineteenth-century writers took advantage of this materiality, but they also struggled with it. Letters could be used to think with, to jot down ideas, and to rehearse arguments that might later appear in print. ${ }^{29}$ They allowed phrenologists in the Pacific and India to imagine they were having a conversation with a gentleman in London or Boston, rather than sweating in the tropics. But letters could also be lost or damaged, contributing to a sense of distance and separation.

\footnotetext{
${ }^{26}$ D. Beales, 'The idea of reform in British politics, 1829-1850', in T. Blanning and P. Wende, eds, Reform in Great Britain and Germany, 1750-1850 (Oxford, 1999), pp. 160-70. See R. Williams, Keywords: a vocabulary of culture and society (London, 1976), pp. 221-2 for further uses of the word 'reform'.

${ }^{27}$ A. Desmond, The politics of evolution: morphology, medicine and reform in radical London (Chicago, IL, 1989) shows how early evolutionary ideas were put to diverse political uses.

${ }^{28}$ N. Hall, 'The materiality of letter writing: a nineteenth-century perspective', in D Barton and N. Hall, eds, Letter writing as a social practice (Amsterdam, 2000).

${ }^{29}$ J. Browne, Charles Darwin: the power of place (2 vols., London, 2002), II, pp. 10-13 also suggests the varied uses of correspondence.
} 
In the case of phrenology, attention to material culture is particularly relevant. As with the global, historians need to distinguish between the material as an analytic category and the material an actors' category. Recent work across a range of disciplines has emphasized the need to integrate objects into the study of the past. ${ }^{30}$ In this article I treat letters as part of this material culture. In taking this approach we gain additional information from postmarks, wax seals and paper. But I also show that phrenologists themselves were attentive to this materiality. They were after all promoting a doctrine of materialism, one often associated with other radical sciences such Robert Grant's transformism. ${ }^{31}$ When the phrenologist Fowler argued that reading could 'exercise' the mind, he meant it literally. ${ }^{32}$ The structure of phrenological books typically reflected this, with chapters devoted to individual organs, inviting the reader to activate different areas of the brain. Combe presented The constitution of man as a kind of mental workout, explaining that 'the best mode of increasing the strength and energy of any organ and function, is to exercise them regularly and judiciously'. ${ }^{33}$

Once we consider correspondence as properly materialized, we can also understand it, like many phrenologists, as a practice of reform in its own right. Composing and sending a letter, particularly when separated by a significant geographic distance, allowed phrenologists to connect apparently local issues to global politics. The very passage of a letter implied a material connection that might otherwise have gone unnoticed. Nineteenth-century political action relied upon establishing exactly this kind of causal connection. ${ }^{34} \mathrm{~A}$ successful campaign for abolition in Britain was only possible once middle-class consumers accepted the link between purchasing sugar in London and the plight of the slave in the West Indies. Yet many of the same consumers did not feel any moral obligation towards slaves outside of

\footnotetext{
${ }^{30}$ For a classic statement, see A. Appadurai, 'Introduction: commodities and the politics of value', in A. Appadurai, ed., The social life of things: commodities in cultural perspective (Cambridge, 1988). P. Joyce, 'What is the social in social history?', Past and Present, 206 (2010), pp. 213-48 invites social historians to pay attention to methodologies grounded in material culture. For a perspective from the history of science, see L. Taub, 'Introduction: reengaging with instruments', Isis, 102 (2011), pp. 689-96.

${ }^{31}$ Desmond, The politics of evolution, pp. 116-20 and van Wyhe, Phrenology, pp. 75-7.

${ }^{32} \mathrm{~J}$. Secord, Victorian sensation: the extraordinary publication, reception, and secret authorship of Vestiges of the Natural History of Creation (Chicago, IL, 2000), pp. 269-75.

${ }^{33}$ G. Combe, The constitution of man (Edinburgh, 1835), p. 34.

${ }^{34}$ T. Haskell, 'Capitalism and the origins of the humanitarian sensibility, Part 1', The American Historical Review, 90 (1985), pp. 339-361.
} 
the British empire, such as those in the United States. Establishing and negotiating these 'moral geographies' was the principal occupation of nineteenth-century reformers. ${ }^{35}$

As birth and property gave way to less tangible notions of respectability, character served as the other dominant concept in nineteenth-century political thought. ${ }^{36}$ Letters in particular were understood to reveal the authentic character of an individual in a way even their public conduct could not. ${ }^{37}$ When we consider reform as a global project, this issue becomes even more pertinent. Correspondence provided a means to assess the trustworthiness of individuals who might never have met. At the same time, character served as the very object of reform. New prisons were designed to produce a permanent change in the character of the inmates, whilst abolitionists debated the relative moral qualities of slaves and slaveholders. By examining slavery, prisons and schools in turn, this article also reveals how the notion of character cuts across different reform projects, allowing campaigners to borrow strategies from one another. In the United States, Combe visited schools and prisons, noting the similarities between the respective systems of discipline. ${ }^{38}$ Many of his correspondents - men and women like Samuel Gridley Howe and Lucretia Mott - were active in both abolitionist politics as well as campaigns for educational and religious reform. ${ }^{39}$ With character occupying such a central role in these debates, phrenology emerged as an effective political language. It provided a universal understanding of human character, one that could apparently be applied in almost any situation, from reading a letter in the Pacific to managing a prison in the United States. Phrenology and correspondence together therefore

${ }^{35}$ R. Huzzey, 'The moral geography of British anti-slavery responsibilities', Transactions of the Royal Historical Society, 22 (2012), pp. 111-39.

${ }^{36}$ A. Burns and J. Innes, 'Introduction', in A. Burns and J. Innes, eds, Rethinking the age of reform: Britain 1780-1850 (Cambridge, 2003), pp. 1-3, S. Collini, 'The idea of 'character' in Victorian political thought', Transactions of the Royal Historical Society, 35 (1985), pp. 29-50 and A. Secord, 'Corresponding interests: artisans and gentlemen in nineteenth-century natural history', The British Journal for the History of Science, 27 (1994), pp. 383-408.

${ }^{37} \mathrm{P}$. White, 'Lives and letters: correspondence and public character in the nineteenth century', in R. Crone, D. Gange and K. Jones, eds), New perspectives in British cultural history, (Cambridge, 2007), pp. 192-5.

${ }^{38}$ S. Tomlinson, Head masters: phrenology, secular education, and nineteenth-century social thought (Tuscaloosa, AL, 2005), pp. 234-8. For a classic study of the relationship between schools and prisons, see M. Foucault, Discipline and punish: the birth of the prison, trans. Alan Sheridan (London, 1997).

${ }^{39}$ On the connection between abolition and other reform campaigns, see the essays collected in C. Bolt and S. Drescher, eds, Anti-slavery, religion, and reform: essays in memory of Roger Anstey (Folkstone, 1980). 
offer an unparalleled opportunity to uncover how politics and science operated on the global stage.

Every spring Charles Caldwell set off from his hometown in Kentucky, travelling down the Mississippi River by paddle steamer, before finally arriving in New Orleans. Once there, he would unpack his collection of phrenological busts, ready to begin his annual lecture tour. At the New Orleans Lyceum, the Governor of Louisiana listened attentively, whilst the local organising committee praised Caldwell for his 'highly intellectual and interesting exposition of the philosophy of the human mind'. Following Caldwell's initial tours in the 1820s, white southerners took an increasing interest in phrenology. Caldwell even complained of competition from itinerant lecturers in Louisiana. ${ }^{40}$ Local enthusiasts in Alabama also printed an account of a 'negro boy' exhibiting exceptional mathematical ability. Despite describing the young slave as a 'living wonder', the authors proceeded to offer the boy's skull as a 'valuable acquisition' to any phrenological collection. ${ }^{41}$ One phrenologist even admitted to acquiring the skull of a slave who had been struck on the head with an axe by his master. ${ }^{42}$ In the south, phrenology and violence went hand-in-hand. Born in North Carolina in the 1770s, and owning slaves himself in Kentucky, Caldwell was no stranger to this world. ${ }^{43} \mathrm{He}$ was also keen to defend it.

Caldwell first broached the subject in a letter. Writing from Lexington in the 1830s, he tentatively asked the phrenologist Combe, 'what think you of my views of Africans and Caucasians?' ${ }^{44}$ Invoking the idea of an omnipotent creator, common to southern arguments against abolition, Caldwell suggested to Combe that 'by original organization and therefore radically and irredeemably, the African is an inferior race. Nothing short of the power that

\footnotetext{
${ }^{40}$ Caldwell to Combe, 1 June 1836, MS7237, f. 94, Combe Papers, and P. McCandless, 'Mesmerism and phrenology in antebellum Charleston: 'Enough of the Marvellous', The Journal of Southern History, 58 (1992), pp. 199-230.

41 'Phrenological Facts', The American Phrenological Journal, 7 (1845), pp. 21-23.

${ }^{42}$ O. Fowler, Phrenology and physiology explained and applied to education and self-improvement (New York City, NY, 1843), pp. 49-50.

${ }^{43}$ C. Caldwell, The autobiography of Charles Caldwell (Philadelphia, PA, 1855), p. 62.

${ }^{44}$ Caldwell to Combe, 14 Sept. 1835, MS7234, f. 83, Combe Papers.
} 
made them can ever raise them to an equality with the Caucasian. ${ }^{45}$ For Caldwell, it was the large 'animal organs', located towards the back of the head, which rendered Africans unfit for freedom. In a long letter to Combe on this subject, Caldwell drew repeated parallels between animals and slaves, writing that 'by good pasture and feeding, you may increase the size of your horses and cows. But you cannot bestow on them the bulk of the rhinoceros or the elephant. ${ }^{46}$ In another, Caldwell wrote that he found the difference between Africans and Caucasians to be 'much greater than the difference in organization between the dog and the wolf; or between the fox and the jackal. Yet they are acknowledged to differ in species. ${ }^{47}$ Abolitionists could not hope to change 'either the Ethiopian's skin or the leopard's spots.' In conclusion, Caldwell argued, 'the Africans must have a master' ${ }^{48}$

Whilst these views were no doubt popular at the New Orleans Lyceum, Caldwell initially preferred to keep them out of print. He wrote to Combe explaining that it was "more than probable that I shall never write any thing for the press on the subject of slavery' ${ }^{49}$ Caldwell's caution reflects his uneasy position at the intersection of northern and southern American society. He certainly enjoyed his time lecturing in the slave states, but Caldwell also derived much of his status from having published in respectable northern periodicals. These included Annals of Phrenology, the official publication of the Boston Phrenological Society. ${ }^{50}$ The secretary of the society, the abolitionist Samuel Gridley Howe, would not have been pleased to learn that one of its contributors was in fact a defender of slavery. For both Caldwell and Combe, correspondence provided a relatively safe space in which to test out their ideas and identities.

Caldwell's long letter on the 'animal organs' reached Combe in September 1839. By this time, Combe was staying in Maine having left Edinburgh in 1838 to conduct a two-year lecture tour of the United States. Relaxing in his hotel by Cape Elizabeth, Combe spent some time preparing his response. The material form of the letter helped (Figure 1). Combe jotted

\footnotetext{
${ }^{45}$ Caldwell to Combe, 12 Aug. 1837, MS7242, f. 46, Combe Papers, and L. Harlow, 'Neither slavery nor abolitionism: James M. Pendleton and the problem of Christian conservative antislavery in 1840s Kentucky', Slavery and Abolition, 27 (2006), pp. 367-89, at pp. 367-8.

${ }^{46}$ Caldwell to Combe, 30 Aug. 1839, MS7249, f. 145, Combe Papers.

${ }^{47}$ Caldwell to Combe, 12 Aug. 1837, MS7242, f. 46, Combe Papers.

${ }^{48}$ Caldwell to Combe, 30 Aug. 1839, MS7249, f. 145, Combe Papers.

${ }^{49}$ Caldwell to Combe, 30 Aug. 1839, MS7249, f. 145, Combe Papers.

${ }^{50}$ C. Caldwell, 'Phrenology vindicated', Annals of Phrenology, 1 (1833), pp. 1-102.
} 


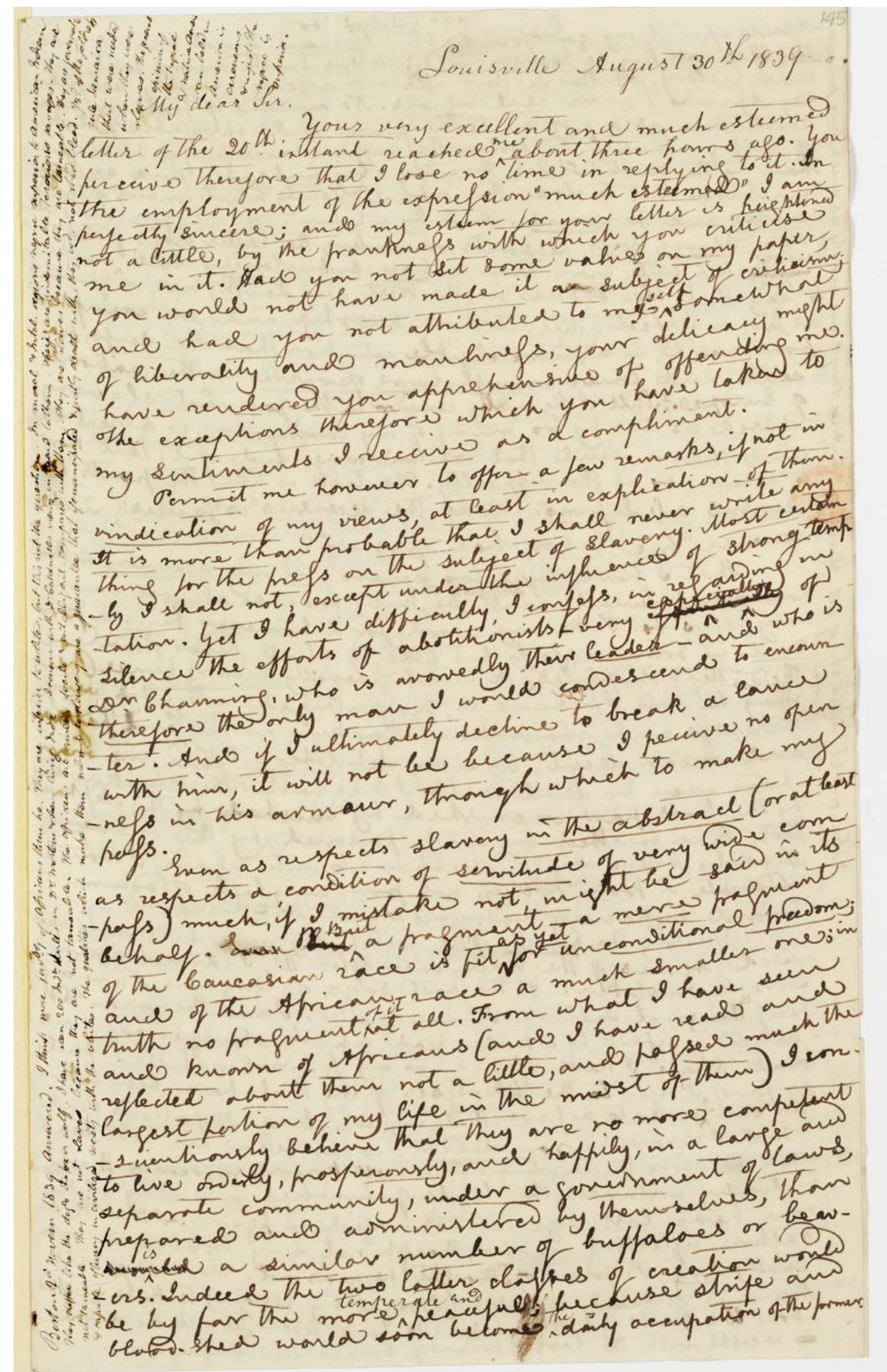

Fig. 1. Combe notes down his thoughts on slavery in the left margin of Caldwell's letter, Caldwell to Combe, 30 August 1839, MS7249, f.145, Combe Papers, National Library of Scotland, UK. 
down his initial thoughts in the margins, writing 'I think more of Africans than he. They are inferior to white, but this is not the question'. It did not matter, as most whites agreed, that Africans possessed inferior brains. What mattered was whether they could be entrusted with freedom. Filling the space to the side of Caldwell's first sheet, Combe compared the character of Africans and Native Americans. Drawing on Caldwell's own animal comparison, he wrote that Native Americans were 'indomitable, ferocious savages. They are not tameable. They are not slaves because they are not tameable'. With the Second Seminole War still raging in Florida, this argument appealed directly to southern fears of the Native American population. In contrast, Combe argued, 'Africans are mild, docile \& intelligent, compared with them. They are slaves because they are tameable'. Here Combe first expressed an idea in note-form which he would later return to in print. Stories of violent slave rebellions in Virginia and Jamaica fuelled white fears of immediate abolition throughout the 1830s. Caldwell himself argued that 'strife and blood-shed would soon become the daily occupation' of the free African. Combe responded to these concerns, arguing that phrenology in fact showed African character to be essentially placid, writing that 'the qualities which make them submit to slavery are a guarantee that if emancipated \& justly dealt with, they wd not shed blood' ${ }^{51}$ Combe later repeated this argument in the 1840 s, first in his Notes on the United States of North America and then in the fifth and expanded edition of his System of Phrenology. ${ }^{52}$ But he first worked it out in the margins of Caldwell's letter.

Still, Caldwell's defence of slavery rested on much more than his dim view of African character. He was adamant that European abolitionists could not understand the conditions of slavery without having visited the southern states themselves. On arriving in the United States, Combe received a letter from Caldwell to this effect: 'You do not like the slaveholding states of the Union. My good friend, shall I tell you why? You have never seen them. ${ }^{53}$ Well aware that Combe planned only to visit the northern states on his lecture tour, Caldwell attempted to change his mind, writing "without sojourning some time among us, you can never depict us aright; because you can never know us aright'. ${ }^{54}$ Here, Caldwell showed his sensitivity to the moral geography of antislavery arguments. ${ }^{55} \mathrm{He}$ also understood

\footnotetext{
${ }^{51}$ Combe's notes on Caldwell to Combe, 30 Aug. 1839, MS7249, f. 145, Combe Papers.

${ }^{52}$ G. Combe, System of phrenology (Edinburgh, 1843), p. 355 and G. Combe, Notes on the United States of North America (3 vols., Edinburgh, 1841), II, p. 78.

${ }^{53}$ Caldwell to Combe, 25 Feb. 1838, MS7245, f. 97, Combe Papers.

${ }^{54}$ Caldwell to Combe, 14 June 1839, MS7249, f. 137, Combe Papers.

${ }^{55}$ Huzzey, 'Moral Geography', pp. 111-39.
} 
the significance of another aspect of abolitionist rhetoric, one that phrenologists were particularly well-placed to engage with. African character was important. But for many, the character of the slaveholders themselves was of greater relevance. ${ }^{56}$ Opponents of abolition often argued that slavery could still be maintained with good conscience, so long as masters acted with care and diligence towards their slaves. Caldwell himself invoked this argument in a letter to Combe, writing 'we profess to be as virtuous, moral, and religious as our brethren of the north... we have much humanity, benevolence, and magnanimity... And those attributes all plead, and plead successfully, for kindness towards our slaves. ${ }^{57}$

After consulting his friends in Boston, including the abolitionist William Ellery Channing, Combe finally took up Caldwell's offer and decided to visit Kentucky and Virginia in April 1840. ${ }^{58} \mathrm{He}$ was not impressed with what he found. Writing in his Notes on the United States of North America, Combe complained that 'nothing can exceed the fertility and beauty of Kentucky; yet slavery makes it languish. ${ }^{59}$ Phrenology itself provided a language of character in which Combe could dismantle proslavery arguments. In the run-up to the abolition of slavery in the West Indies in 1833, The Phrenological Journal in Edinburgh had printed an article entitled 'Colonial Slavery Tested by Phrenology'. The author of the article argued that 'phrenologically, we know enough of the human faculties of the average endowment... to come to the conclusion that the Negro slave cannot be humanely treated; that he must be over-worked, under-cared for, and cruelly punished by so many slave-holders. ${ }^{60}$ Combe returned to these ideas in correspondence. He was polite enough not to identify Caldwell by name, but he was nonetheless disparaging when it came to slaveholding character. In a letter to the American abolitionist Maria Weston Chapman, he wrote, 'how is it possible for a people so moral, religious, enlightened, and free to defend and practice slavery? ${ }^{91}$ In another letter he even criticized the former president John Quincy Adams for trying to placate slaveholders in the District of Colombia. Adams had claimed that abolition would be unconstitutional. Combe had never met Adams, but he had seen a bust: 'I

\footnotetext{
${ }^{56}$ B. Fladeland, Men and brothers: Anglo-American antislavery cooperation (Champaign, IL, 1972), p. 292.

${ }^{57}$ Caldwell to Combe, 14 June 1839, MS7249, f. 137, Combe Papers.

${ }^{58}$ Combe to Channing, 28 Mar. 1838, MS7395, f. 12, Combe Papers.

${ }^{59}$ Combe, Notes, III, pp. 333-4.

60 'Colonial slavery tested by phrenology', The Phrenological Journal, 8 (1832-1834), p. 83.

${ }^{61}$ Combe to Chapman, 22 Nov. 1845, MS7390, f. 215, Combe Papers.
} 
write this from his head... If Mr Adams had had a larger Conscientiousness, he would have felt that there was a jarring between his principle $\&$ his conclusion' ${ }^{62}$

\section{II}

The American abolitionist Lucretia Mott understood the materiality of correspondence better than most. On finishing a letter, she would turn it over, fold it, and stamp it with her own wax seal. Once dried, the impression revealed a kneeling female slave, chained and surrounded by the words 'Am I Not a Woman and a Sister?' (Figure 2). This image had been adapted in the 1820s from the original Josiah Wedgwood antislavery medallion to better reflect the concerns of female abolitionists. ${ }^{63}$ As a wax seal, it allowed women like Mott to push the boundaries of polite female correspondence. ${ }^{64}$ In contrast to Caldwell, Mott first made contact with Combe in person rather than on paper. The two met in Philadelphia in 1839 at a Quaker meeting house ${ }^{65}$ Combe's wife Cecilia was also travelling with him and the two stayed with Mott and her husband James whilst in the city. Mott had read Combe's Constitution of man and soon received an invite to join the Philadelphia Phrenological Society, one of the few to admit women. ${ }^{66}$ Later in the century, she even allowed Lorenzo Fowler to perform a phrenological analysis on her children. ${ }^{67}$ And unlike Caldwell, Mott's letters are full of the details of family life, including the state of her health and the progress of her husband's textile business. ${ }^{68}$

${ }^{62}$ Combe to Mott, 15 July 1839, MS7396, f. 72, Combe Papers. His view was later confirmed when he met Adams in Washington, DC in February 1840, Combe, Notes, II, pp. 106-7.

${ }^{63}$ C. Hamilton, 'Hercules subdued: the visual rhetoric of the kneeling slave', Slavery and Abolition, 34 (2013), pp. 631-652, at pp. 631-633 and C. Midgley, Women against slavery: the British campaigns, 1780-1870 (London, 1995), p. 97.

${ }^{64}$ Letter-writing manuals instructed on the appropriate use of wax seals in this period, L. Schultz, 'Letterwriting instruction in 19th-century schools in the United States', in D. Barton and N. Hall, eds, Letter writing as a social practice (Amsterdam, 2000), pp. 117-20.

${ }^{65}$ Combe, Notes, II, p. 49.

${ }^{66}$ Mott to Combe, 8 September 1839, MS7251, f. 158 and Mott to Combe, 10 Apr. 1840, MS7256, f. 60, Combe Papers.

${ }^{67}$ Mott to Combe, 26 Apr. 1847, MS7287, f. 28, Combe Papers.

${ }^{68}$ K. Dierks, 'The familiar letter and social refinement in America, 1750-1800', in D. Barton and N. Hall, eds, Letter writing as a social practice (Amsterdam, 2000), pp. 31-42 discusses the importance of familial correspondence in demonstrating social refinement. 


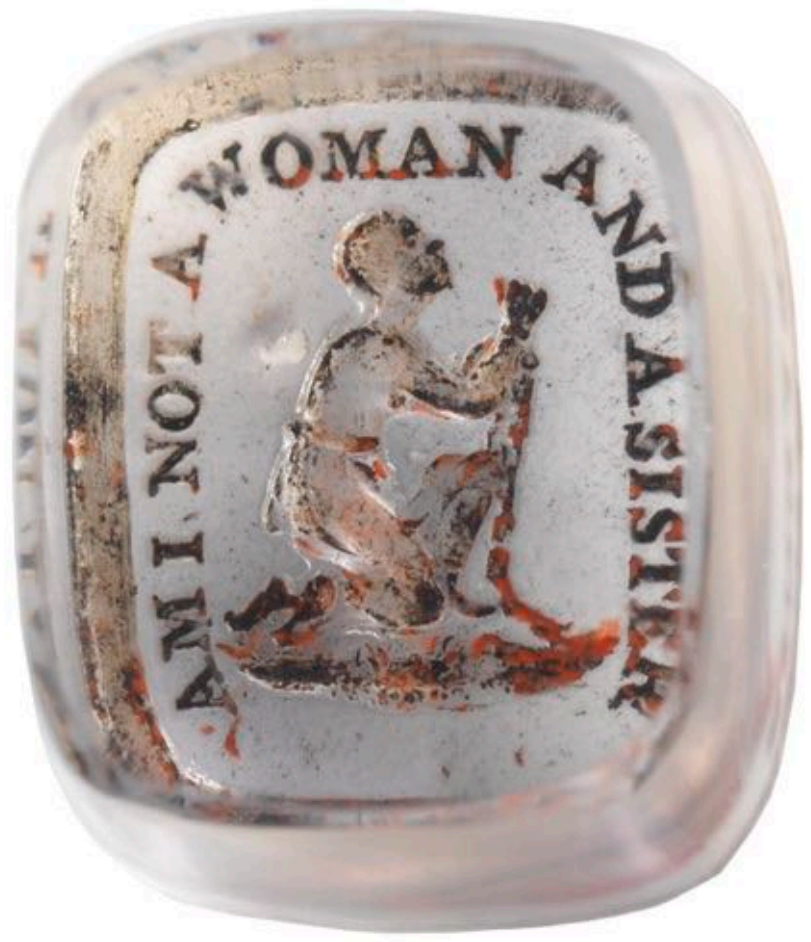

Fig. 2. 'Am I not a woman and a sister?' glass seal, ZBA2460, National Maritime Museum, London, UK.

Phrenology and family life might have been deemed suitable subjects of correspondence for middle-class women, but the case was not so clear with slavery. Caldwell himself had been scathing of female abolitionists, describing Harriet Martineau as a 'disappointed old maid' following the publication of her Society in America. Caldwell recognized that these were 'perhaps harsh terms to apply to a woman' ${ }^{69}$ But that was the point. For him, antislavery was unladylike. Within this climate, Mott's wax seal provided a means to turn even routine familial correspondence into political expression. ${ }^{70}$ Combe saw this figure each time he opened one of Mott's letters, no matter what the contents. Soon enough, he became comfortable with the idea of discussing abolition with her, albeit in gendered terms. In a letter to Channing, Combe praised Mott, describing her 'strong, bold, independent intellect' which was 'combined with exquisite gentleness, delicacy \& taste'. He

\footnotetext{
${ }^{69}$ Caldwell to Combe, 7 Oct. 1838, MS7245, f. 99, Combe Papers.

${ }^{70}$ D. Barton and N. Hall, 'Introduction', in D. Barton and N. Hall, eds, Letter writing as a social practice (Amsterdam, 2000), pp. 7 note the gendered forms letter-writing could take.
} 
also noted that that she had 'embraced Phrenology strongly \& sees its moral power \& practical tendencies'. ${ }^{71}$

Combe and Mott agreed on the basic principle that slavery was a sin and ought to be abolished. However, they did not agree on the means. Before leaving Edinburgh, Combe had overseen the publication of an article in The Phrenological Journal entitled 'On the American Scheme of Establishing Colonies of Free Negro Emigrants on the Coast of Africa' ${ }^{72}$ This presented a positive view of the American colony of Liberia situated in West Africa. Liberia had been founded by the American Colonization Society as part of its plans to abolish slavery by freeing slaves and sending them to Africa. Advocates of colonisation believed slavery was inhibiting the industrial development of the United States. They also believed that African slaves were not capable of integrating into white civilized society. ${ }^{73} \mathrm{On}$ the other side of the Atlantic, colonisation appealed to Combe and his colleagues in Edinburgh. It provided a means to reconcile a belief in the inferiority of the African mind with antislavery sentiment. In 1833, The Phrenological Journal declared that 'we heartily approve [of] the American Colonization Society'. The article also praised Liberia as 'a community of Africans, without a white to claim the white's ascendancy'. For the author, phrenology also explained why it was so important to separate the white and black populations: "when mixed, the white and Negro must stand to each other in relation of a superior and inferior race, with all the injurious effects of such a relation on both. ${ }^{, 74}$

Following the end of slavery in the West Indies, British abolitionist efforts increasingly turned towards the United States throughout the 1830s. Given this growing transatlantic interest, the American Colonization Society also began to seek support from major British antislavery figures. Indeed, The Phrenological Journal article noted that the 'venerable [Thomas] Clarkson... has lived to see and applaud it in the strongest terms' ${ }^{75}$ The American Colonization Society also attempted to align itself with similar British efforts, including Thomas Buxton's Society for the Civilisation of Africa. With the British government still yet to formally recognize Liberia as a legitimate colony, the reception of the

\footnotetext{
${ }^{71}$ Combe to Channing, 23 Apr. 1839, MS7396, f. 52, Combe Papers.

72 'On the American scheme of establishing colonies of free negro emigrants on the coast of Africa', The Phrenological Journal, 8 (1832-1834), pp. 145-60.

${ }^{73}$ B. Tomek, Colonization and its discontents: emancipation, emigration, and antislavery in antebellum Pennsylvania (New York City, NY, 2011), p. 3.

74 'On the American scheme', pp. 152-160.

75 'On the American scheme', p. 159.
} 
American Colonization Society in Britain had the potential to influence the path taken by antislavery efforts in the United States. ${ }^{76}$ And Combe, as a best-selling author and prolific writer on American society, certainly held sway over a large number of British readers. Mott knew all of this well. In fact, she suggested that Combe might wish to publish a selection of her correspondence on slavery in Britain. ${ }^{77}$ For Mott, as for many other northern antislavery campaigners, particularly Quakers, colonisation was not abolition. Mott wanted British abolitionists to recognize this as well. She was therefore dismayed to learn of Combe's support for colonisation and, lamenting the limits of the medium, wrote a letter in June 1839 beginning, 'I wish, in this space, I could make thee understand why colonizationists and abolitionists cannot harmonize' ${ }^{78}$

Combe received Mott's letter whilst staying in the White Mountains, New Hampshire. He recognized that Mott's letter required a lengthy response, beginning 'I forsee I will fill my sheet'. Combe also suggested that he could potentially give Mott what she wanted, writing 'if I shall publish any work on America on my return, I should like very much to print your letter in it... It contains a great deal of interesting information, well stated, \& in a short space.' Still, Combe was unwilling to change his own opinion. He recognized the significance of the reports Mott had quoted, and began by attempting to reassure her that he was not a covert supporter of slavery himself, writing 'I embrace without reservation, your fundamental principle that 'man cannot rightfully hold property in man', and I am satisfied, from your quotation, that many members of the Colonization Society, hold the opposite opinion.' Combe also admitted that the American Colonization Society 'may have erroneous views \& even bad motives at the bottom'. 'Nevertheless', he argued, 'their scheme... may be capable of being turned to good account in virtue's cause, \& it appears to me that it will be so turned. ${ }^{79}$

In a final and ultimately fruitless effort to get Combe to change his mind on the subject of colonisation, Mott pointed out that 'the coloured citizens of the free states have proselytised against such removal'. In fact, she noted, free African Americans had opposed colonisation 'long before Wm L Garrison denounced it, and before an antislavery society was

\footnotetext{
${ }^{76}$ Fladeland, Men and brothers, p. 279.

${ }^{77}$ Mott to Combe, 8 Sept. 1839, MS7251, f. 52, Combe Papers.

${ }^{78}$ Mott to Combe, 13 June 1839, MS7251, f. 183, Combe Papers.

${ }^{79}$ Combe to Mott, 15 July 1839, MS7396, f. 72, Combe Papers.
} 
found in this country. ${ }^{, 80}$ Mott was right. Frederick Douglass, himself a former Maryland slave, had argued that 'colonization is out of the question'. Douglass was equally critical of phrenology's role in bolstering slavery. In a later lecture at the Western Reserve College in Ohio, Douglass argued that 'it is fashionable now, in our land, to exaggerate the differences between the negro and the European.' He went on to explain that 'if, for instance, a phrenologist... undertakes to represent in portraits, the difference between the two races - the negro and the European - he will invariably present the highest type of the European, and the lowest type of the negro' (Figure 3). Douglass linked this misrepresentation of African mental capacity directly to slavery, concluding 'by making the enslaved a character fit only for slavery, they excuse themselves for refusing to make the slave a freeman' ${ }^{81}$

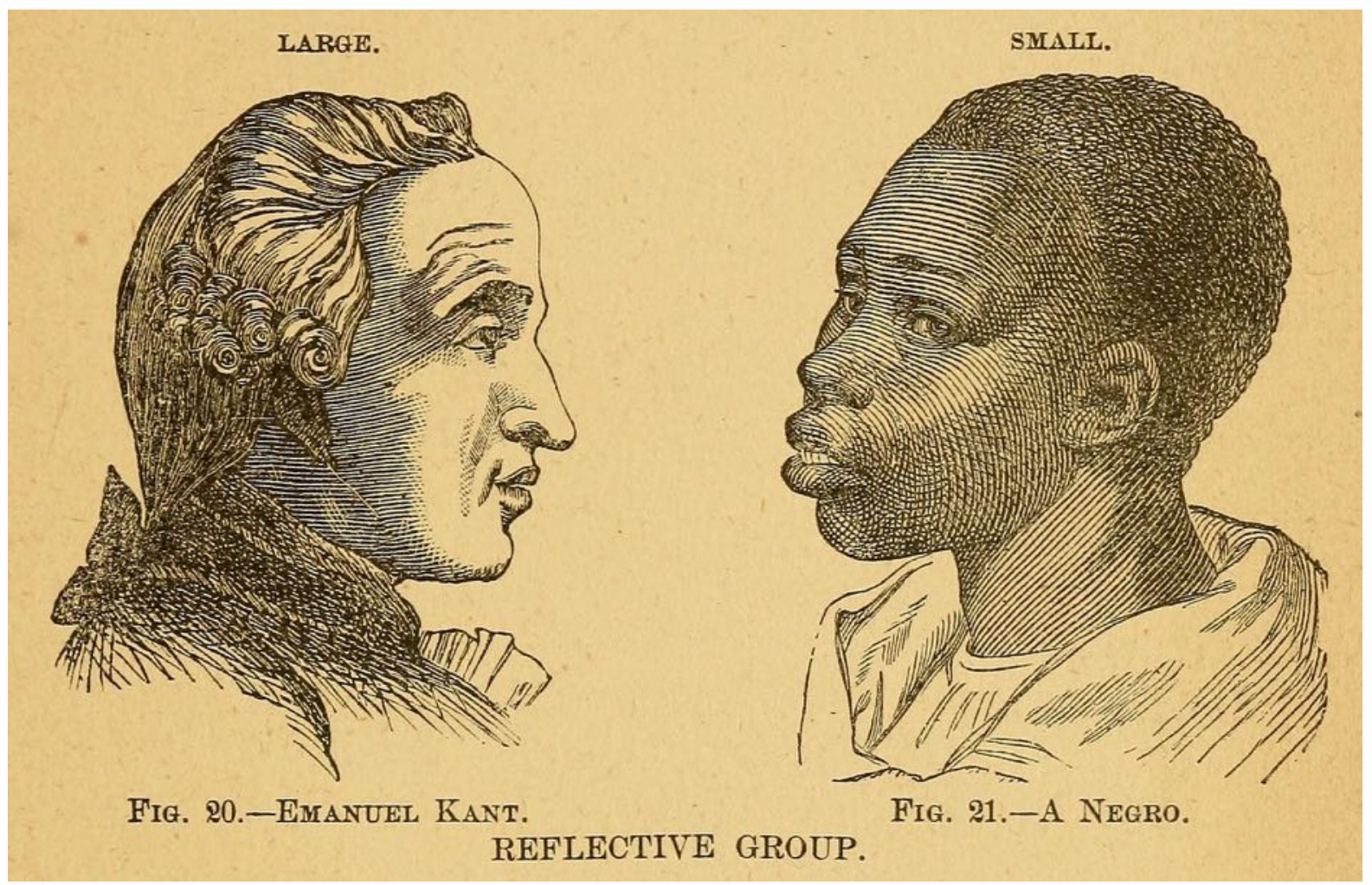

Fig. 3. A phrenological comparison of European and African character, S. Wells, How to read character: a new illustrated hand-book of phrenology (New York, NY, 1891), p. 33.

\footnotetext{
${ }^{80}$ Mott to Combe, 8 Sept. 1839, MS7251, f. 185, Combe Papers.

${ }^{81}$ F. Douglass, The claims of the negro ethnologically considered (Rochester, NY, 1854), pp. 20-35 (italics in original).
} 
Douglass's critique of phrenology provides a brief glimpse into the world of black counter-narratives opposing European racial science. ${ }^{82}$ But this world was carefully segregated, not just physically but also intellectually. In fact, the 'color line' separating whites from blacks was sometimes stronger in correspondence than in daily life. ${ }^{83}$ Combe met a number of African Americans during his tour of the United States. These included a free hotel manager in Philadelphia, whom Combe described as possessing 'a brain that would do no discredit to an European', alongside enslaved labourers in Kentucky. ${ }^{84}$ And when Douglass visited Britain in the 1840s, Combe welcomed him into his home in Edinburgh. The two ate breakfast together alongside the British abolitionist George Thompson and the American abolitionist William Lloyd Garrison. Phrenology was the chief topic of conversation. Douglass recalled that Combe 'looked at all political and social questions through his peculiar mental science... Phrenology explained everything to him, from the finite to the infinite.' Douglass was impressed by what he heard, having recently read Combe's Constitution of Man. In fact, Douglass singled out this book as one of the few phrenological works containing a fair portrayal of African character. ${ }^{85}$

Yet despite these convivial meetings, Combe and Douglass never exchanged a single letter. More broadly, Combe managed a correspondence network that stretched across the United States, Africa, India and the Pacific. It took in factory workers and aristocracy as well as women and children. But over the course of his life Combe never wrote or received a single letter from an African American, even though many, including Douglass, were both interested in phrenology and could afford to pay for transatlantic postage. In a medium in which character remained the final arbiter, Combe's belief that the black mind was ultimately 'inferior to white' proved too difficult to overcome. ${ }^{86}$

\footnotetext{
${ }^{82}$ B. Rusert, 'The science of freedom: counterarchives of racial science on the antebellum stage', African American Review, 45 (2012), pp. 291-308.

${ }^{83}$ F. Douglass, 'The Color line', The North American Review, 132 (1881), pp. 567-577. Secord, 'Corresponding Interests', p. 397 argues that correspondence 'accentuated class differences'. It seems to have had the same effect on racial difference too.

${ }^{84}$ Combe, Notes, II, p. 48.

${ }^{85}$ F. Douglass, The life and times of Frederick Douglass (London, 1882), pp. 299-301.

${ }^{86}$ Combe's notes on Caldwell to Combe, 30 Aug. 1839, MS7249, f. 145, Combe Papers.
} 
Alexander Maconochie watched as the ship carrying the bundle of letters he had written over the previous six months dipped below the horizon. Stationed on the penal settlement of Norfolk Island, a small volcanic rock in the Pacific Ocean, he was over 1000 miles north-east of the New South Wales coast. ${ }^{87}$ Once they arrived in Sydney, the letters addressed to Britain would then travel a further 14,000 miles round the Cape of Good Hope, taking over six months to reach Bristol ${ }^{88}$ It would be at least another year before he received a reply. And so, despite living amongst over 1,500 people, Maconochie felt isolated. On the island he had no one with which to discuss his developing regime of 'penal science' ${ }^{89}$ Correspondence provided the outlet Maconochie was looking for. He could forget the alien landscape of coral reefs and Malayan convicts, replacing it with a gentlemanly world of polite discussion.

On first writing to Combe from Norfolk Island in June 1841, Maconochie imagined the two were having a conversation, writing 'I note down now to talk to you of all these matters. ${ }^{90}$ With little prospect of a reply in the near future, if at all, the notion of 'talking' with Combe was largely rhetorical. The letter allowed Maconochie to conjure up a respectable and familiar context in which to work through his ideas. He could look back to the early 1820s when he and Combe had both been living in Edinburgh, meeting up to discuss phrenology and prison reform. ${ }^{91}$ Back on Norfolk Island, the idea of conversing with Combe once again seemed appealing. Maconochie set down the details of his 'experiment' in prison discipline, suggesting that Combe and his fellow phrenologists would take interest in the 'great moral questions so involved'. Maconochie began by describing the problems Norfolk Island posed. The settlement housed 'the refuse of other colonies' and, prior to his arrival in 1840 , had been organized under a 'horrid system of brute coercion' ${ }^{92}$ Under the former superintendent, convicts laboured knee-deep in the sea, cutting stone in the 'wet

\footnotetext{
${ }^{87}$ M. Hoare, Norfolk Island: an outline of its history 1774-1977 (Brisbane, 1969), p. 4.

${ }^{88}$ Timings based on study of postmarks, particularly Maconochie to Combe, 16 June 1841, MS7261, f. 44, Combe Papers.

${ }^{89}$ R. Hughes, The fatal shore: a history of the transportation of convicts to Australia, 1787-1868 (London, 2003), pp. 499-502.

${ }^{90}$ Maconochie to Combe, 16 June 1841, MS7261, f. 44, Combe Papers.

${ }^{91}$ Maconochie to Combe, 27 Sept. 1834, MS7233, f. 28, Combe Papers.

${ }^{92}$ Maconochie to Combe, 16 June 1841, MS7261, f. 44, Combe Papers.
} 
quarry' by the coral reef..$^{93}$ If they refused or acted with insubordination, they would be savagely beaten. For this reason, the Governor of New South Wales, Ralph Darling, considered Norfolk Island 'the extremest [sic] punishment short of death' ${ }^{94}$ Only the worst reoffenders, those already sentenced to transportation to New South Wales or Van Diemen's Land, would be transferred to Norfolk Island. Maconochie explained to Combe that nowhere on earth were there 'individuals less fitted than any others possibly could be' for his 'system of moral influence'. ${ }^{95}$ The implication was simple but powerful: if Maconochie's prison reform could work on Norfolk Island, it could work anywhere.

At the centre of Maconochie's vision was the 'mark system'. Under this regime, sentences were measured by the accumulation of marks rather than by time. Instead of a seven-year stint on Norfolk Island, a convict would need to earn approximately 6,000 marks before being released. Marks could be gained through labour and good behaviour. Convicts could also opt to form groups and accumulate marks together. ${ }^{96}$ But they also needed to spend marks in order to acquire basic provisions and, if they desired, further luxuries. ${ }^{97}$ Maconochie even made the convicts pay for access to a library of 'Moral and Religious works' purchased for $£ 50$ in Sydney. These books were to be 'improving' and to 'open the mind to a perception of the value of minute distinction' ${ }^{98}$ Combe's Constitution of man, available in New South Wales at the time, no doubt fitted the bill. Finally, Maconochie abolished all physical punishment on the island. Instead, convicts would forfeit marks if they misbehaved. ${ }^{99}$ And so, in common with many other penal reformers of his generation, Maconochie believed the prison should mirror an ideal capitalist society. ${ }^{100} \mathrm{He}$ explained to Combe:

\footnotetext{
${ }^{93}$ Hughes, Fatal shore, p. 463.

${ }^{94}$ Hoare, Norfolk island, p. 36.

${ }^{95}$ Maconochie to Combe, 16 June 1841, MS7261, f. 44, Combe Papers.

${ }^{96}$ Hughes, Fatal shore, pp. 500-1.

${ }^{97}$ Maconochie to Combe, 16 June 1841, MS7261, f. 44, Combe Papers.

${ }^{98}$ Maconochie to Gipps, 25 February 1840, in F. Watson, ed., Historical records of Australia (26 vols., Sydney, 1914), I, p. 535.

${ }^{99}$ Hughes, Fatal shore, p. 501.

${ }^{100}$ D. Melossi and M. Parvani, The prison and the factory: origins of the penitentiary system, trans. G. Cousin (London, 1981).
} 
I have nowhere heard it said that a poor family in England ever comes to distress... that had over accumulated by its own exertions $£ 5$ in a Savings Bank: and that is the great principle that I desire to apply to Prisoners. ${ }^{101}$

For Maconochie, criminal minds could not be reformed through fear of physical punishment. Instead, convicts needed to learn the value of good work discipline and money management. The prisoners he encountered on Norfolk Island were 'hostile... to the function of society'. Yet, as he explained to Combe, 'it is with their aid, not merely their submission or neutrality, that I may succeed'. Maconochie did however recognize that many believed the Norfolk Island convicts to be 'irredeemably bad'. Was every criminal really capable of being reformed? If not, then his system would be deemed a failure from the start. Phrenology allowed Maconochie to challenge the idea of an incorrigible mind. He explained to Combe that his system was based on 'Phrenological principles' and that he believed 'the general intellect of the criminal population is for the most part greatly under-stated'. On Norfolk Island, Maconochie observed, 'there are many excellent heads among them' ${ }^{102}$

Still, it wasn't just the character of the convicts Maconochie needed to worry about. As with abolition, the mental and moral qualities of the prison officer played a significant role in reform debates. Maconochie himself was not a popular man in the colonies. Prior to his appointment to Norfolk Island, Maconochie penned a damning report based on his experience at the Hobart penal settlement on Van Diemen's Land in 1837. He forwarded the report, describing the system there as 'cruel, uncertain, prodigal', directly to the Parliamentary Select Committee on Transportation in Westminster. ${ }^{103}$ Maconochie was soon unwelcome on Van Diemen's Land and accepted a transfer to Norfolk Island. Still, the colonial officials in New South Wales did their best to get their own back. Rumours began to circulate in the Sydney press that Maconochie's eldest daughter, Mary Ann, had been seduced by a convict and fallen pregnant. And when Maconochie held an extravagant party for the prisoners complete with rum and fireworks, albeit in honour of Queen Victoria's birthday, he was ridiculed. The colonial secretary, Edward Deas Thomson, dispatched a short letter calling on Maconochie to rein in his own 'sanguine temperament'. ${ }^{104}$ In writing to

\footnotetext{
${ }^{101}$ Maconochie to Combe, 16 June 1841, MS7261, f. 44, Combe Papers.

${ }^{102}$ Maconochie to Combe, 16 June 1841, MS7261 f. 44, and Maconochie to Combe, 12 Nov. 1844, MS7273, f. 44, Combe Papers.

${ }^{103}$ Hughes, Fatal shore, p. 409.

${ }^{104}$ Hughes, Fatal shore, pp. 503-13.
} 
Combe, Maconochie therefore hoped to project a favourable impression of both his scheme and his own character back in Britain. Maconochie admitted in his letter that 'you must have heard of my great controversy in this hemisphere' but he wished Combe to know that he was 'for now successful'. Even the 'old mutineers' on the island were displaying 'earnest, energetic \& trustworthy tempers'. ${ }^{105}$

When Combe finally received the letter in December 1841, he too felt a sense of distance. The parcel had clearly come a long way, having been stamped with four postmarks including 'New South Wales' and 'Norfolk Island' (Figure 4). The conversation Maconochie had imagined over six months ago in the Pacific would have to wait. Combe chose not to reply until Maconochie had returned to Britain in $1844 .{ }^{106}$ By that time, Combe had completed lecture tours of both the United States and Northern Europe. In the course of these he had visited the Eastern State Penitentiary in Philadelphia, Auburn Prison in New York, and the House of Correction in Hamburg. ${ }^{107} \mathrm{He}$ had also received a letter from Henry Spry of the Bengal Medical Service detailing the imprisonment, trial and execution of a group of thieves in Northern India. ${ }^{108}$ And so looking over his correspondence again in the mid-1840s, Maconochie's letter in hand, Combe was now in a position to imagine a system of prison discipline stretching across North America, Europe, India and the Pacific.

The result was a pair of articles entitled 'Norfolk Island' and 'Penal Colonies' published in The Phrenological Journal. Combe acknowledged the problematic geography of penal reform in the first article, writing "what is transacted in a remote isle of the Pacific Ocean, without a newspaper, is never seen, and not heard of.${ }^{109}$ But Combe wanted to do much more than bring the mark system to Britain. Reflecting on the similarity between Norfolk Island and the penitentiaries he had seen in the United States, Combe advanced the idea of a regime of prison discipline capable of operating in any environment. The mark system was 'a practical embodiment of phrenological principles... calculated to work

\footnotetext{
${ }^{105}$ Maconochie to Combe, 16 June 1841, MS7261 f. 44, and Maconochie to Combe, 12 Nov. 1844, MS7273, f. 44, Combe Papers.

${ }^{106}$ Combe to Maconochie, 31 Oct. 1844, MS7388, f. 782, Combe Papers.

${ }^{107}$ Combe, Notes, II, p. 2, 326, and G. Combe, 'Mr Combe on the institutions of Germany', The Phrenological Journal, 10 (1836-1837), pp. 698-706, at p. 698

${ }^{108} \mathrm{~K}$. Wagner, 'Confessions of a skull: phrenology and colonial knowledge in early nineteenth-century India', History Workshop Journal, 69 (2010), pp. 27-51, at pp. 38-45.

${ }^{109}$ [G. Combe], 'Norfolk Island - reform in convict treatment', The Phrenological Journal, 15 (1842), pp. 2232 , at p. 23.
} 


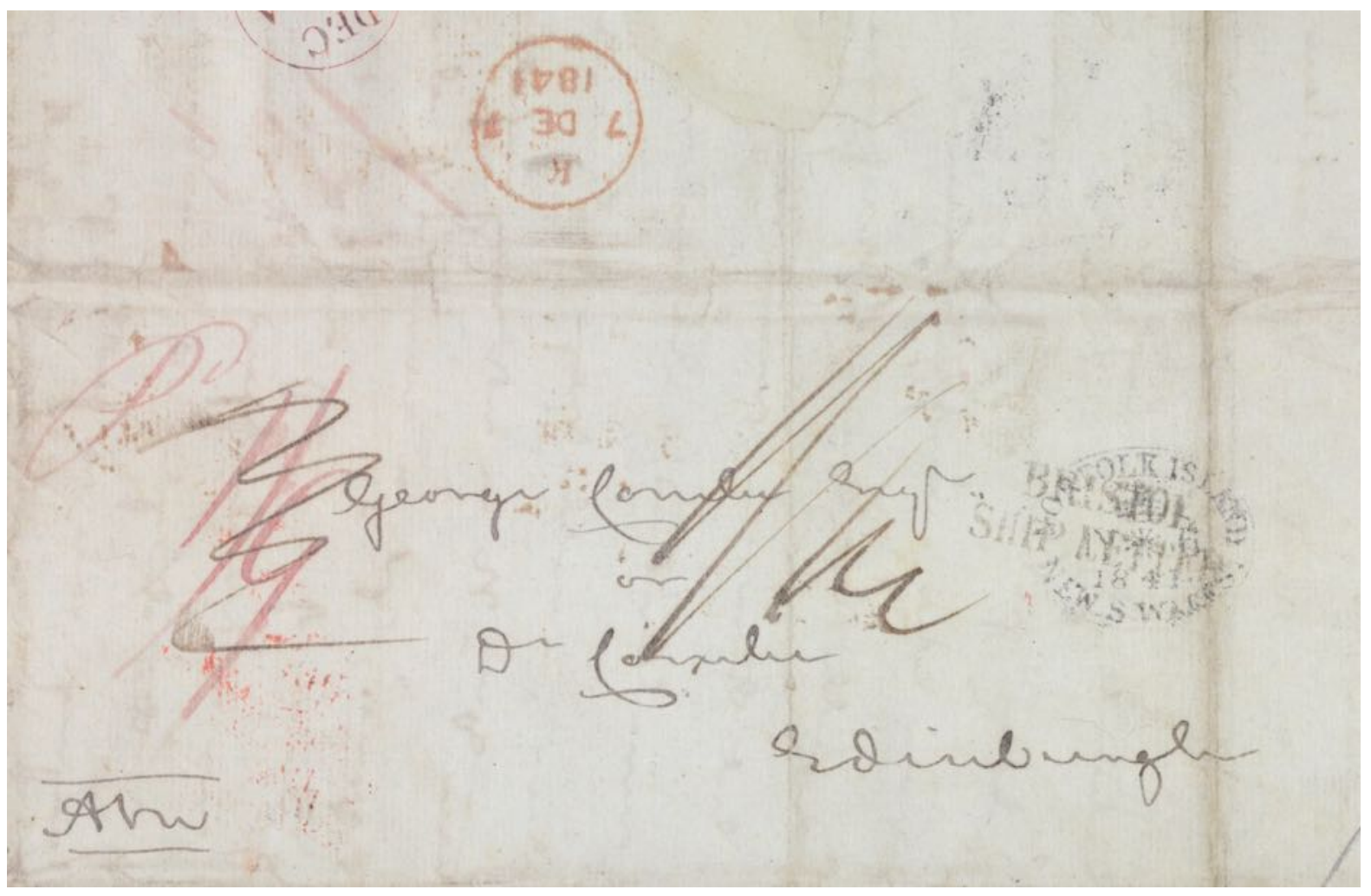

Fig. 4. Postmarks on letter from Maconochie to Combe, 16 June 1841, MS7261, f.44, Combe Papers, National Library of Scotland, UK.

certainly and easily, at any distance, and under any executive power'. The language of phrenology allowed Combe to identify a global criminal class, irrespective of locality. The 'thugs' in Northern India, the African American convicts in the Eastern State Penitentiary, and the mutineers on Norfolk Island were all united by cerebral organisation. Criminals the world over possessed 'large animal, active and powerful intellectual, and very deficient moral organs'. Maconochie's scheme was no longer an 'experiment' confined to the Pacific. Rather, it was 'applicable to prisons and penitentiaries at home as well as abroad'. ${ }^{110}$

With readers in Britain, France, Prussia, India and the United States, The Phrenological Journal was certainly a powerful medium through which to advance the idea of a global regime of prison discipline. But Combe also reinforced this through correspondence. In the United States, reformers continued to debate the relative merits of two different systems of prison discipline. Under the separate system at the Eastern State Penitentiary in Philadelphia, convicts spent their entire sentence in isolation. In contrast, under the silent system at Auburn Prison in New York, convicts spent the days labouring together but were forbidden to communicate. Supporters of both systems advanced the ideal

${ }^{110}$ G. Combe , 'Penal colonies', The Phrenological Journal, 18 (1845), pp. 101-122. 
of reforming the soul rather than merely punishing the body. ${ }^{111}$ Samuel Gridley Howe, secretary of the Boston Phrenological Society, was one of those in favour of the separate system. Like many others, he believed that Auburn Prison relied too much on the whip to enforce a regime of silence. ${ }^{112}$ However, Combe had not been impressed with the separate system during his own visit to the Eastern State Penitentiary on a freezing cold January morning in 1839. As he explained in his Notes on the United States of North America, 'this system is not founded on, nor in harmony with, a sound knowledge of the physiology of the brain'. In fact, 'the system of entire solitude... leaves the moral faculties still in a passive state, and without means of vigorous active exertion'. ${ }^{113}$ In short, long-term solitary confinement was too extreme, tending to produce mental deficiency rather than reform.

After reading Notes on the United States of North America, Howe wrote to Combe in 1846 explaining that he was 'surprised to find that I come to a different conclusion from you on the advantages of the separate system' ${ }^{114}$ But Combe was not going to change his mind. Earlier that year he had received favourable reports of the influence of phrenology at Auburn and Sing Sing Prison in New York, also conducted under the silent system. As Combe himself observed, all books except for the Bible were forbidden at the Eastern State Penitentiary. ${ }^{115}$ In contrast, reading was much more widely permitted at Auburn and Sing Sing. Combe already earnestly believed that reading improved the criminal mind. He had even received a letter from an inmate who had read The Constitution of Man whilst incarcerated at Rochester Prison in upstate New York. ${ }^{116}$ But Combe probably couldn't have imagined just how far his ideas had penetrated. In February 1846 he received a letter from Elisha Hurlbut, a lawyer in New York City. Hurlbut explained that he had met the female prison warden at Sing Sing. Incredibly, she was 'a phrenologist - and teaches phrenology to the unfortunate beings under her charge'. Not only that, Hurlbut explained, but 'she often takes the 'Constitution of Man' in hand and lectures from it to the female prisoners in the chapel of their prison'. ${ }^{117}$ With converts on the inside, and a greater emphasis on actively

\footnotetext{
${ }^{111}$ M. Meranze, Laboratories of virtue: punishment, revolution, and authority in Philadelphia, 1760-1835 (Chapel Hill, NC, 1996), p. 1.

${ }^{112}$ Meranze, Laboratories of virtue, pp. 295-6.

${ }^{113}$ Combe, Notes, II, pp. 13-15.

${ }^{114}$ Howe to Combe, [undated 1846], MS7275, f. 110, Combe Papers.

${ }^{115}$ Meranze, Laboratories of virtue, p. 294.

${ }^{116}$ Mackenzie to Combe, 29 Nov. 1839, MS7251, f. 130, Combe Papers.

${ }^{117}$ Hurlbut to Combe, 27 Feb. 1846, MS7280, f. 79, Combe Papers.
} 
improving the mind, there was really no contest between the silent system in New York and the separate system in Pennsylvania. Combe replied to Howe, politely dismissing the merits of the Eastern State Penitentiary, writing 'I regret to observe that you \& I differ in regard to the advantages of the solitary system of prison discipline'. He did, however, recommend that Howe read the latest number of The Phrenological Journal as it included an 'article on Norfolk Island' ${ }^{118}$

From then on, Maconochie's mark system became an effective means for Combe to express his ideal of a global system of prison discipline. He forwarded copies of Maconochie's privately-printed pamphlet, The management of prisons in the Australian colonies, to both Hurlbut and Horace Mann, the American politician and educational reformer. ${ }^{119}$ Mann, also a subscriber to The Phrenological Journal, had recently completed his own tour of the Prussian schools and prisons. ${ }^{120}$ He thanked Combe for the pamphlet and suggested that the application of phrenology 'to Criminal Legislation, Jurisprudence, \&c \&c, will, in time, I have no doubt, work revolutions in those departments'. ${ }^{121}$ Combe wrote to Maconochie again in 1846 informing him of the great reach his scheme now enjoyed: 'I have commended your mark system in letters to my American friends, as an admirable practical realisation of the principles which they already approve of'. ${ }^{122}$ And so, through correspondence, Maconochie's mark system found a global audience of phrenological reformers.

Bathing in the Hooghly River, just to the north of Calcutta, a small group of Bengali boys could hear the school bell ringing. At 7am each morning they dried themselves and walked the short distance from the river to the modest bamboo schoolhouse at Monirampore. Once there, they were taught English and Sanskrit by a local Brahmin, no doubt hoping to proceed to Hindu College or Sanskrit College in the city. From the outside, this school could easily

\footnotetext{
${ }^{118}$ Combe to Howe, 23 Feb. 1846, MS7390, f. 321, Combe Papers.

${ }^{119}$ Hurlbut to Combe, 7 Oct. 1846, MS7280, f. 80 and Mann to Combe, 28 Feb. 1845, MS7276, f. 111, Combe Papers.

${ }^{120}$ M. Hindus, Prison and plantation: crime, justice, and authority in Massachusetts and South Carolina, 17671878 (Chapel Hill, NC, 1980), p. 220.

${ }^{121}$ Mann to Combe, 1 Oct. 1840, MS7256, f. 27e, Combe Papers.

${ }^{122}$ Combe to Maconochie, 23 Aug. 1846, MS7390, f. 496, Combe Papers.
} 
have been mistaken for any one of the hundreds of traditional pathshala operating in Bengal at the time. ${ }^{123}$ But in early nineteenth-century India, another phrenological 'experiment' was underway. In June 1825 George Murray Paterson founded what he described as 'nothing less than a Phrenological School on the banks of the Hooghly'. ${ }^{124}$ It was the first of its kind in the world.

Paterson had joined the East India Company as an assistant surgeon in 1818 and, like Maconochie, he knew Combe from his time as a young man in Edinburgh. ${ }^{125} \mathrm{He}$ was also an early and avid supporter of phrenology, having read Combe's Essays on phrenology shortly before leaving Britain. ${ }^{126}$ Thankfully for Paterson, Calcutta was a lot better connected than Norfolk Island. Attached to the 16th Bengal Infantry at Barrackpore from December 1824 onwards, he maintained a steady correspondence with phrenologists in both Britain and the United States. Every morning a Bengali postal runner, or dak, arrived at the officers' headquarters. With Paterson's letters packed into a satchel, the runner would then travel the 15 miles south to the Calcutta General Post Office on the Chowringhee Road. Without regular steam shipping from Bengal in this period, the letters were sent by sail, arriving in Britain between four and six months later. Those addressed to the United States would then take another month to cross the Atlantic. ${ }^{127}$

In his first letter to Combe from Bengal, Paterson described himself as 'the Champion of Phrenology in the East'. ${ }^{128} \mathrm{He}$ went on to give an account of the meetings of the Calcutta Phrenological Society. Founded in March 1825, the society sought to provide a regular course of phrenological lectures in the city as well as to undertake a comprehensive 'Oriental

\footnotetext{
${ }^{123}$ On the foundation of Hindu College, and other educational establishments in Bengal during this period, see K. Raj, Relocating modern science: circulation and the construction of knowledge in South Asia and Europe, 1650-1900 (New Delhi, 2006), pp. 159-79.

${ }^{124}$ Paterson to Combe, 20 July 1825, MS7216, f. 46, Combe Papers and Paterson to Bell, [1825], MSS2/023201, College of Physicians of Philadelphia, PA, USA (henceforth, 'College of Physicians'). On phrenology and race more generally in South Asia, see S. Kapila, 'Race matters: orientalism and religion, India and beyond c.1770-1880', Modern Asian Studies, 41 (2007), pp. 471-513.

${ }^{125}$ Assistant-Surgeons' Papers, IOR/L/MIL/9/370, f. 170, British Library, London, UK.

${ }^{126}$ Paterson to Combe, 10 May 1823, MS7211, f. 7, Combe Papers.

${ }^{127}$ Timings based on study of postmarks, particularly Paterson to Combe, 23 Apr. 1825, MS7216, f. 47, Combe Papers.

${ }^{128}$ Paterson to Combe, 20 July 1825, MS7216, f. 46, Combe Papers.
} 
anthropology'. ${ }^{129}$ Paterson told Combe that they had recently held a debate on 'the use of this System in improving Education'. He had also delivered 'a course of six lectures on the principles \& practice of phrenology' at the Asiatic Society in Calcutta. ${ }^{130}$ In another letter to the American physician John Bell, corresponding secretary of the Philadelphia Phrenological Society, Paterson described how he had nurtured a 'nascent appetite for phrenological studies in Calcutta, by distributing elementary books \& busts' ${ }^{131}$ Like other voluntary associations in the city at the time, the Calcutta Phrenological Society maintained strong ties with the British colonial elite. The president was Clarke Abel, physician to the Governor General of Bengal, whilst a number of East India Company merchants attended the meetings held each month in the library of The Bengal Hurkaru newspaper on Tank Square. ${ }^{132}$ With the support of the colonial medical establishment, the phrenologists found their place amidst a broad range of scientific lecturers operating in early nineteenth-century Calcutta, from James Dinwiddie's spectacle of galvanism on Cossitollah Street to David Ross's chemical experiments at Hindu College. ${ }^{133}$

But Barrackpore, where Paterson lived and worked most days, was not urban Calcutta. Writing to Bell again in the summer of 1825, Paterson was taking a break from lecturing in the metropolis, 'the weather being so intensely hot for two months to come'. Whilst most of the other members of the Calcutta Phrenological Society lived in the centre of the city near Fort William, Barrackpore and neighbouring Monirampore were much more rural. In his letter to Bell, Paterson described how he had 'taken an opportunity while living in quiet cantonments, to try an experiment which proved eminently successful beyond my most sanguine expectations'. The 'Phrenological School of Munerampoor' was the result of that experiment. Paterson suggested that, given the American phrenologists were advocating

\footnotetext{
${ }^{129}$ Paterson to Combe, 23 Apr. 1825, MS7216, f. 47, Combe Papers, Paterson to Bell, [1825], College of Physicians, and Calcutta annual register and directory (Calcutta, 1831), p. 313.

${ }^{130}$ Paterson to Combe, 20 July 1825, MS7216, f. 46, Combe Papers, and Paterson to Bell, [1825], College of Physicians.

${ }^{131}$ Paterson to Bell, [1825], College of Physicians.

${ }^{132}$ Paterson to Bell, [1825], College of Physicians.

${ }^{133}$ Raj, Relocating modern science, p. 178 and S. Nair, “'Bungallee House Set on Fire by Galvanism': natural and experimental philosophy as public science in a colonial metropolis (1794-1806)', in B. Lightman, G. McOuat and L. Stewart, eds, The circulation of knowledge between Britain, India and China: the earlymodern world to the twentieth century (Leiden, 2013), p. 52
} 
for their own educational reforms, "it will be perhaps interesting... to learn something regarding the progress of the true \& plenary System of anthropology in Asia'. ${ }^{134}$

The school was modelled on a traditional pathshala, 'built of bamboo \& brick' on a plot provided rent free by a local Bengali landlord, or zamindar (Figure 5). ${ }^{135}$ Paterson began by emphasising the need for a phrenological analysis of both teachers and pupils. He described seeking out 'a native schoolmaster in the village - who came \& had his head examined'. Eventually, Paterson selected 'a Brahmin' with 'a fine configuration of a head', paying him 'one gold Mohur a month', or approximately fifteen rupees. The pupils, twentyfive Bengali boys aged between two and twelve years, were then arranged into classes based on Paterson's own phrenological analysis of their heads. He described how 'small classes were formed of those whose heads manifested the greatest similitude in the three regions'. It was also 'necessary to insulate boys from the dissimilitude of their developments'. The school day was then divided into three as well, representing the major divisions of the phrenological organs. From 7am to 9am the boys exercised the 'animal region', from 11am to $1 \mathrm{pm}$ the 'intellectual region', and from $3 \mathrm{pm}$ to $5 \mathrm{pm}$ the 'moral region'. Paterson then personally measured the progress of the boys with a pair of callipers. He described this practice in his letter to Bell:

On entrance every lad's head was manipulated, measured \& registered in a book kept at the school for the purpose, and every month afterwards it was regularly measured again, so that any slightest alteration might be noted with extreme accuracy.

Looking over the entries in the ledger at the end of 1825, Paterson concluded that the school had proved successful in demonstrating 'the fruits of a Phrenological course of instruction'. In fact, Paterson told Bell, 'most of the lads had so improved in appearance that the uncles \& aunts \& cousins who lived at some distance $\&$ had not seen them during these 4 months, could scarcely recognize them'. ${ }^{136}$

As with prisons and plantations, the character of a school also depended upon the character of its proprietor. But whilst the intellectual and moral qualities of the Bengali pupils had apparently improved, the same could not be said for Paterson. David Drummond,

\footnotetext{
${ }^{134}$ Paterson to Bell, [1825], College of Physicians.

${ }^{135}$ P. Acharya, 'Education in Old Calcutta', in S. Chaudhuri, ed., Calcutta: the living city (2 vols., Oxford, 1990), I, pp. 86-8.

${ }^{136}$ Paterson to Bell, [1825], College of Physicians.
} 


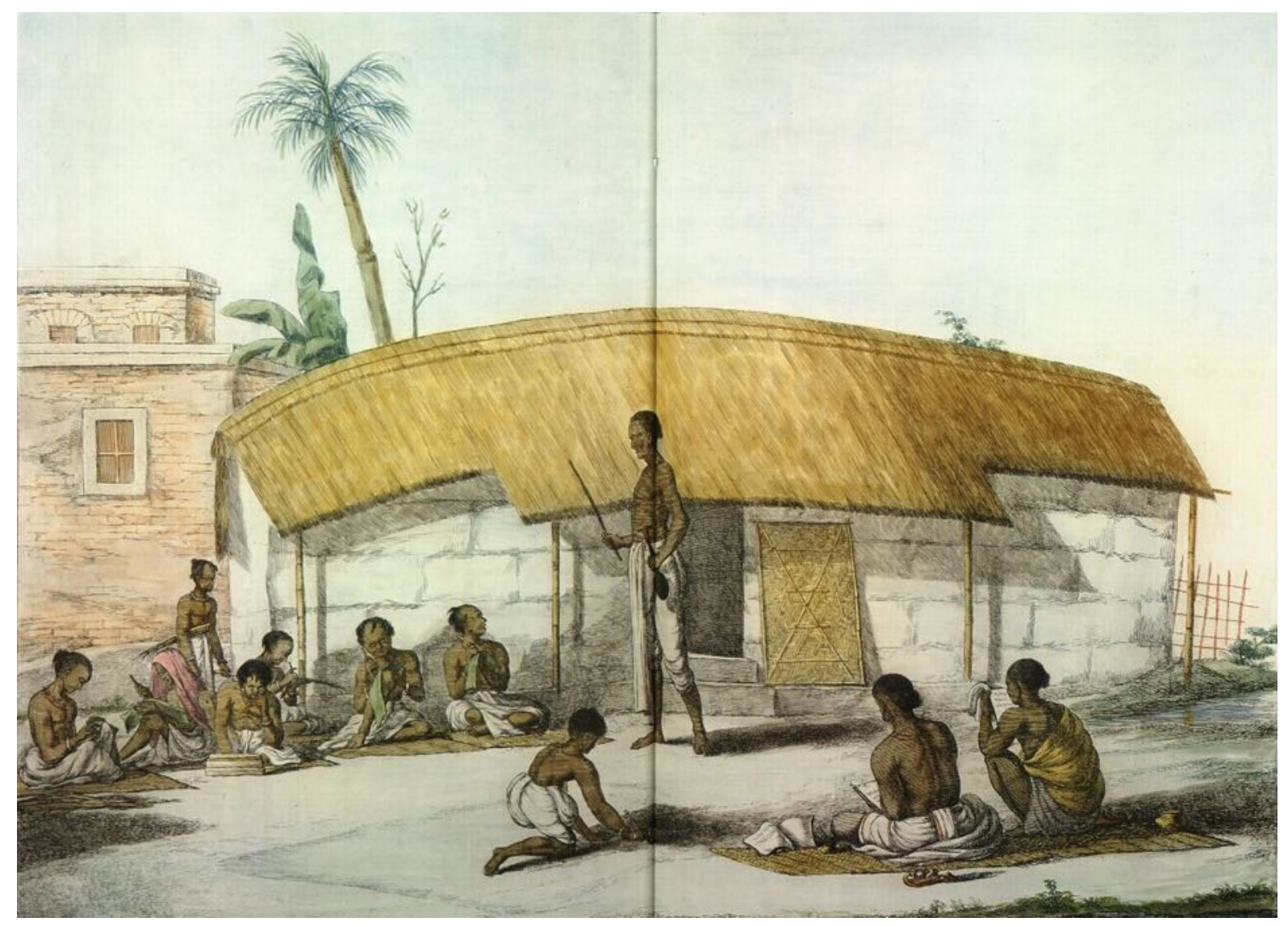

Fig. 5. George Murray Paterson's phrenological school was modelled on a traditional pathshala as represented in F. Solvyns, Les hindoûs (4 vols., Paris, 1808-1812), III, plate 10.1.

founder of the Durrumtollah Academy in Calcutta, argued that the phrenological schoolmaster was characterized by 'childishness' and 'credulity'. ${ }^{137}$ Another of Paterson's opponents went even further. James Beatson, an East India Company officer, wrote to Combe declaring, 'Dr. P. is not in a fit state to have any thing to say to such matters. He drinks like a fish! And his brain is considered to be... affected by the liberal potations of brandy to which he has habituated himself' ${ }^{138}$ (Given Paterson admitted to poor health - 'my liver having suffered much during my stay in Sumatra' - this might have been a fair description.) $)^{139}$ Beatson recommended that Combe should send no further books to either Paterson or the phrenological school. Paterson retaliated, attacking Drummond as 'puerile and erratic' and describing another opponent, John Adam of the Medical and Physical Society of Calcutta, as

\footnotetext{
${ }^{137}$ D. Drummond, Objections to phrenology: being the substance of a series of papers communicated to the Calcutta Phrenological Society (Calcutta, 1829), p. 62, 89 and 113.

${ }^{138}$ Beatson to Combe, 28 Jan. 1827, MS7219, f. 3, Combe Papers.

${ }^{139}$ Paterson to Combe, 10 May 1823, MS7211, f. 7, Combe Papers.
} 
'unstable as water' ${ }^{140}$ But the damage was done, and Combe agreed it was better for Beatson to sell off the remaining copies of his books rather than give them to the alcoholic phrenologist. ${ }^{141}$

Whatever Paterson's problems, his school nonetheless generated interest far beyond rural India. Correspondence connected these reformers together materially but it was phrenology itself that provided a language through which to imagine a universal system of instruction. Whether in Boston or Bengal, phrenologists established educational reform on two basic principles. First, the three-fold division of the brain into intellectual, moral and animal faculties. Second, the materiality of the mind. For phrenologists, all education was ultimately physical education. The brain was just another muscle. So whilst Paterson's school was certainly influenced by his belief in the weakness of the Bengali mind and body, it also reflected a broader phrenological attitude towards education, one reinforced through international correspondence. Paterson was in fact writing to Bell in Philadelphia and Combe in Edinburgh precisely because he understood his scheme as more generally applicable. He summed up his view on education to Bell as follows:

I am certain the true \& plenary System of Education is by addressing our labours to every organ in particular. Exercising those that are too weak in the balance of the whole; and Quieting those that are too strong for the same balance. ${ }^{142}$

When Paterson wrote to Combe, he also explicitly conceived of his work as part of a global movement, writing 'I hope now the Societies in Europe, Asia, and America may illuminate each other. ${ }^{143}$

Much to Paterson's delight, phrenological schools did begin to pop up in the United States. Horace Mann had just finished reading the Allen and Ticknor 1834 edition of Combe's Constitution of man when he was appointed Secretary of Education to the State of Massachusetts. ${ }^{144}$ Combe and Mann later met in a train carriage on the way to a school convention in New England. ${ }^{145}$ This proved to be the beginning of an enduring friendship,

\footnotetext{
${ }^{140}$ Drummond, Objections, p. 89 and Paterson to Bell, [1825], College of Physicians.

${ }^{141}$ Combe to Beatson, 23 May 1826, MS7383, f. 317, Combe Papers.

${ }^{142}$ Paterson to Bell, [1825], College of Physicians.

${ }^{143}$ Paterson to Combe, 23 Apr. 1825, MS7216, f. 47, Combe Papers.

144 Tomlinson, Head masters, p. $\mathrm{x}$

${ }^{145}$ Combe, Notes, I, 64-65.
} 
one sustained over the years through regular transatlantic correspondence. Combe came to consider Mann 'another brother to me' and found his character to be beyond reproach. ${ }^{146}$ Mann was both manly and righteous, 'a perfect moral Hercules' in Combe's eyes. ${ }^{147}$ The geographic distance actually worked to increase the bond Combe felt. He told Mann it was 'delightful to find kindred spirits, full of great thoughts \& feelings of world-embracing philanthropy, in all countries'. ${ }^{148}$ Combe only wished the penny post would extend to the United States. ${ }^{149}$ In any case, Mann returned the complement, describing The Constitution of Man as 'the greatest book that has been written for centuries' and 'the only practical basis for education'. ${ }^{150}$ His good friend and fellow educational campaigner, Samuel Gridley Howe, also found Combe's books to be exemplary. He wrote to the phrenologist in March 1839, seven months before the two met in Boston, writing that 'no words can express the obligation I feel to the great author of the System of Phrenology'. ${ }^{151}$

Mann and Howe were serious about the role of phrenology in school reform. The three-fold division of the brain shaped the very meaning of the project, with Howe suggesting that education should be directed to the 'physical, intellectual, \& moral nature' of students. ${ }^{152}$ When Mann became president of Antioch College in the $1850 \mathrm{~s}$ he put these ideas into practice, explaining to Combe that the tutors and managers were all 'avowed phrenologists'. ${ }^{153}$ Like Paterson's school in India, the day was divided into physical, intellectual and moral instruction. Each morning the students would rise at 6am to eat breakfast and attend chapel before exercising with their teachers for at least three hours. This would then be followed by five hours of lectures and another four hours of independent study, the latter intended to promote self-discipline and moral reflection. ${ }^{154}$ As director of the Perkins School for the Blind in Boston, Howe also structured education around phrenology. He even made sure it was taught, writing to Combe in 1839 to inform him that the "upper

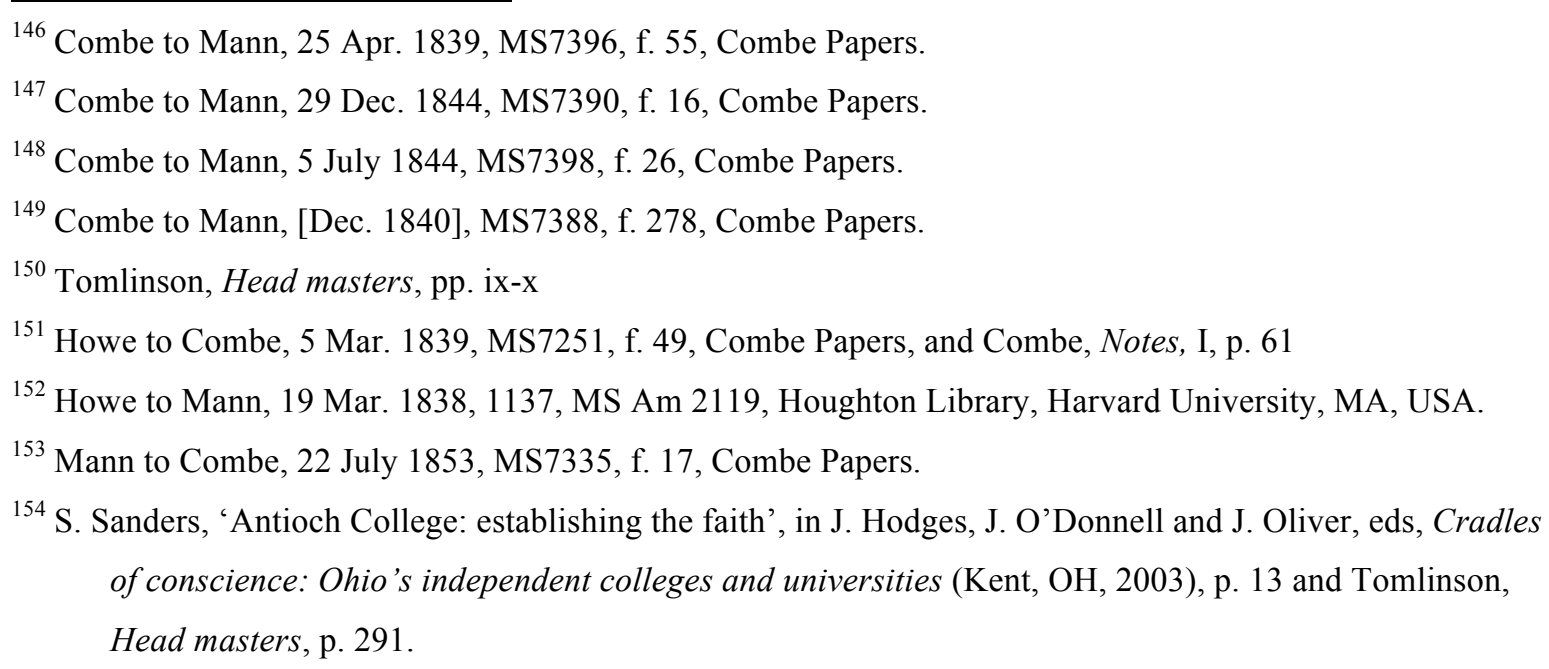


classes are all instructed in the general principles of intellectual philosophy... I have known many who have taken a deep interest in the philosophy of phrenology' ${ }^{155}$

Combe was impressed by the progress of phrenology in American schools and promised Mann that he would 'call public attention both in Europe \& America to your bright example'. Combe kept to his word and, in April 1841, informed Mann that he had 'written an account of your system \& doings \& have actually got it adopted by the Edinburgh Review! ${ }^{156}$ This was a coup, given that the same periodical had published a damaging critique of phrenology in the $1820 \mathrm{~s}$. But it was precisely because phrenology had travelled to the United States and returned in the form of Mann's letters that Combe was afforded such an opportunity back in Britain. The article was still published anonymously, which was not unusual for The Edinburgh Review, but Combe did manage to emphasize the role of phrenology in American educational reform. He quoted directly from Mann, insisting that schoolmasters should have 'a knowledge of the human mind as the subject of improvement' ${ }^{157}$ By sending phrenology on a circuit, beginning in Calcutta and then taking in the Atlantic world, the phrenologists ultimately enhanced both the reach and the credibility of their respective campaigns. Local reform gained momentum through global exchange.

\section{$\mathbf{V}$}

Moving from the slave plantations of the United States to the rural schools of Bengal, this article has developed two overarching arguments. First, correspondence allowed phrenologists to build reform as a global project. Second, phrenology itself provided a means to express these ideas in terms of a universal understanding of human character. The materiality of correspondence proved central to this argument. For phrenologists, the passage of a letter implied a connection between disparate locales, reinforcing a sense of moral responsibility and common purpose. In light of this, there is an important relationship between the global history of correspondence presented in this study and the ways in which the phrenologists themselves thought about the global. The history of science is therefore well-placed to contribute to broader debates within global intellectual history. Samuel Moyn

\footnotetext{
${ }^{155}$ Howe to Combe, 29 Sept. 1840, MS7255, f. 101, Combe Papers.

${ }^{156}$ Combe to Mann, 30 Apr. 1841, MS7388, f. 511, Combe Papers.

${ }^{157}$ [G. Combe], 'Education in America', Edinburgh Review, 73 (1841), pp. 486-502, at p. 492.
} 
and Andrew Sartori argue that we need to treat the global 'as a native or actor's category'. ${ }^{158}$ But more often than not, this has led to a narrow focus on Hegel and Marx. ${ }^{159}$ The history of phrenology demonstrates how the sciences, and particularly the sciences of the mind, need to be understood as part of a much more varied intellectual tradition, ranging from universal and world history to political economy and anthropology. ${ }^{160}$ Phrenologists promoted their own materialist vocabulary in order to understand connections and comparisons between different regions and reform projects. And most importantly, the means through which they communicated these ideas actually reflected the content of those ideas. Correspondence was a material practice of communication to match a materialist philosophy of the mind. ${ }^{161}$

Additionally, by treating communication as a material act, we can better recognize the limits of the global. ${ }^{162}$ Phrenology did not go everywhere, nor all at once. Taken together, Combe's correspondence represents a particular political, racial and gendered geography. The runners, mail-coaches and steamships which carried Combe's letters mapped, albeit unevenly, an expanding British empire. And despite Orson Fowler's hopes, the penny post never developed into a truly international system. The Imperial Penny Post, which initially excluded Australia, New Zealand and South Africa, only started life in 1898 and didn't survive much beyond the First World War. ${ }^{163}$ Throughout the nineteenth century, international correspondence remained an expensive activity, effectively excluding the majority of working-class campaigners as well as colonized subjects. Most strikingly,

\footnotetext{
${ }^{158}$ Moyn and Sartori, 'Approaches to global intellectual history’, p. 17.

${ }^{159}$ S. Subrahmanyam, 'Global intellectual history beyond Hegel and Marx', History \& Theory, 54 (2015), pp. 126-37.

${ }^{160}$ On the history of global history, see S. Conrad, What is global history? (Princeton, NJ, 2016), pp. 17-36. On the sciences as part of global history, see S. Sivasundaram, 'Introduction: global histories of science', Isis, 101 (2010), pp. 95-7. The term 'global' did not take on its modern meaning until the 1890 s, see 'global, adj.', Oxford English Dictionary Online, <http://www.oed.com/view/Entry/79019>, 2009. Combe and the phrenologists of the nineteenth century therefore used terms such as 'globe', 'world' and 'universal' rather than the specific word 'global'. (I am grateful to Simon Schaffer for this reference and comment.)

${ }^{161}$ J. Secord, 'Knowledge in transit', Isis, 95 (2004), pp. 654-72, at p. 656 argues that we should understand 'knowledge as communication'.

${ }^{162}$ For a critique of global histories which ignore limits, see F. Cooper, Colonialism in question: theory, knowledge, history (Berkley, CA, 2005), pp. 91-112 and S. Hodges, 'The global menace', Social History of Medicine, 25 (2012), pp. 719-28.

${ }^{163}$ Staff, The Penny Post, pp. 126-40, 149-52.
} 
Combe's archive is dominated by the English language. Whilst he did know a little French and German, Combe chose to write in English even when addressing his Continental counterparts. On writing to Casimir Broussais of the Paris Phrenological Society, Combe concluded his letter by stating, 'I trust that you read English... as I cannot write French with facility or correctness'. ${ }^{164}$ Similarly, when Nobin Chunder Bose, a Bengali phrenologist, wrote to Combe from Calcutta in the 1840 s, he described the "cerebral organization of the Hindoos' in English rather than his native language. ${ }^{165}$ The history of correspondence uncovered in this article is therefore one geography among many: Bose was also reading Bengali editions of phrenological books printed in Calcutta, such as Rabdallav Das's Manatatwa sarsangraha, whilst African Americans like Douglass discussed and critiqued phrenology in their own periodicals and lecture halls. ${ }^{166}$

Despite these limits, correspondence was still an important means through which many phrenologists came to see the relationship between different reform projects. Slavery was a particularly common point of comparison. When Maconochie learned of the interest his scheme had generated in the United States, he wrote to Combe expressing his belief that 'the cause I advocate seems to me even more important to humanity... than that of the abolition of Black Slavery' ${ }^{167}$ In fact, like many other campaigners opposing transportation, Maconochie compared the existing penal settlements in New South Wales to the slave plantations in the United States. According to Maconochie, only the mark system 'would remove that taint of slavery which, at present, corrupts every portion of it ${ }^{\prime}{ }^{168}$ Similarly, whilst Mott began her correspondence with Combe on the basis of a shared interest in slavery, she too was prompted to consider the relationship between abolition and other reform agendas. Combe suggested that the Philadelphia race riots of the 1840s could partly be explained by an ineffective school system, writing 'the riots were much promoted by large boys who have been expelled from the public schools... cast loose on society with all their propensities untamed, and reckless of all authority human or divine' ${ }^{169}$ In light of this, he sent a copy of his Remarks on national education to Mott. ${ }^{170}$ She concurred with Combe,

\footnotetext{
${ }^{164}$ Combe to Broussais, 9 May 1832, MS7385, f. 297, Combe Papers.

${ }^{165}$ Bose to Combe, 7 Aug. 1846, MS7278, ff. 33-34, Combe Papers.

${ }^{166}$ Kapila, 'Race matters', pp. 502-11 and Rusert, 'The science of freedom', pp. 301-4.

${ }^{167}$ Maconochie to Combe, 31 Aug. 1844, MS7273, f. 30, Combe Papers.

${ }^{168}$ Combe, 'Penal colonies', p. 114.

${ }^{169}$ Combe to Mann, 29 Dec. 1844, MS7390, f. 16, Combe Papers.

${ }^{170}$ Combe to Mott, 28 Oct. 1847, MS7391, f. 139, Combe Papers.
} 
expressing her belief that 'the efforts to spread education... will prove one of the successful means, to bring about the desired result' ${ }^{171}$ In the course of a couple of letters, the abolition of slavery suddenly depended upon enacting phrenological school reforms. William Lloyd Garrison's cousin was even reported to have started teaching phrenology to freed slaves in Jamaica. ${ }^{172}$

These developments were not confined to abolitionists. Caldwell also came to see the relation between slavery and reform more generally. In the 1830 s he published an article in The Phrenological Journal entitled 'New Views of Penitentiary Discipline' in which he discussed both the silent system at Auburn and the transportation of convicts to New South Wales. Adopting the same language he used to describe the slave population, Caldwell declared that crime was 'the product of mere animal propensity' and that 'to reform a criminal, then, you must make him less of an animal, and more of a human being' ${ }^{173}$ This was a period in which the African American convict population weighed heavily on the minds of penal reformers, with the Boston Prison Discipline Society describing 'the degraded character of the colored population' in its first annual report. The Massachusetts State Prison even suggested sending African American inmates to Liberia. ${ }^{174}$ For Caldwell, phrenology explained the relationship between freedom and mental character in both the prison and on the plantation: the 'animal organs' dominated in both slaves and convicts. Phrenology ultimately provided a universal language of mental character through which to bring together these diverse institutions - from schools to slavery - under a single political banner. ${ }^{175}$ It was therefore through global exchange that the very notion of 'reform' came into focus. ${ }^{176}$

With individuals and society connected through a common understanding of human character, it didn't take long for reform to transform into something more dramatic. In July 1848, Combe received his first letter from a revolutionary. ${ }^{177}$ Gustav Struve, former editor of

\footnotetext{
${ }^{171}$ Mott to Combe, 28 May 1850, MS7310, f. 27, Combe Papers.

172 'Miscellany', The American Phrenological Journal, 5 (1843), p. 288.

${ }^{173}$ C. Caldwell, 'New Views of Penitentiary Discipline and Moral Education and Reformation of Criminals', The Phrenological Journal, 7 (1831-1832), pp. 385-410, at pp. 387-8 (italics original).

${ }^{174}$ Hindus, Prison and plantation, pp. 178, 236-7.

${ }^{175}$ It wasn't until the 1820 s that abolitionists came to associate their work with the term 'reform', D. Turley, The culture of English antislavery, 1780-1860 (London, 2003), p. 183.

${ }^{176}$ On the development of 'reform' as a political ideology, see A. Burns and J. Innes, 'Introduction', and J. Innes, ' 'Reform' in English public life', and D. Beales 'The idea of reform'.

${ }^{177}$ Struve to Combe, 3 July 1848, MS7297, f. 115, Combe Papers.
} 
Zeitschrift für Phrenologie in Heidelberg, had already hinted at a change in his political outlook. In doing so, he revealed how phrenology could be tied to a new political language of revolution, one that many started to contrast with reform. In a letter sent just before the revolutions of 1848, Struve had explained that 'phrenology is at the bottom of all my doings... it has only made clear, what before was unclear, firm and cast iron, what before was wavering and uncertain'. ${ }^{178}$ Struve stuck to convictions and in April 1848 joined the Hecker Uprising in Baden as part of the unrest which was sweeping across Europe. Although the uprising ended in defeat, Struve managed to escape to Switzerland. Unsurprisingly, news of revolution in Europe was greeted with condemnation by the political elite in Britain. Holed up in the Swiss border town of Rheinfelden, Struve read the damning editorials published in The Times. He was therefore keen to emphasize both the legitimacy and moral value of his action to his British correspondents and penned the following letter to Combe:

Very soon all men of character and courage were convinced that nothing could be expected, neither from the several German princes, nor from the assembly of Frankfort... It became clear to every thinking man that the old system of slavery would be kept up unless the princes should be driven away by force.

Appropriately enough, Struve composed this letter on what can only be described as revolutionary notepaper (Figure 6). ${ }^{179}$ The intricate printed design featured an image of his fellow republican Friedrich Hecker and was headed with the revolutionary slogan 'Freiheit, Gleichheit, Verbrüderung' (Liberty, Equality, Fraternity).

Despite Struve's choice of stationary, Combe was not convinced. Once again, the meaning of reform was open to contestation. For Struve, reform needed to be won from below, through the wholesale rejection of aristocratic society. But for Combe, reform had to come from above, through legislation and government. Like many others in Britain at the time, he labelled the alternative 'revolution'. ${ }^{180}$ What's more, for Combe, phrenology explained exactly why political change could never legitimately come about through

\footnotetext{
${ }^{178}$ Struve to Combe, 28 Aug. 1846, MS7282, f. 103, Combe Papers.

${ }^{179}$ Struve to Combe, 9 Aug. 1848, MS7297, f. 117, Combe Papers.

${ }^{180} \mathrm{P}$. Wende, '1848: reform or revolution in Germany and Great Britain', in T. Blanning and P. Wende, eds, Reform in Great Britain and Germany, 1750-1850 (Oxford, 1999) and J. Innes, ' Reform' in English public life', pp. 86-8.
} 


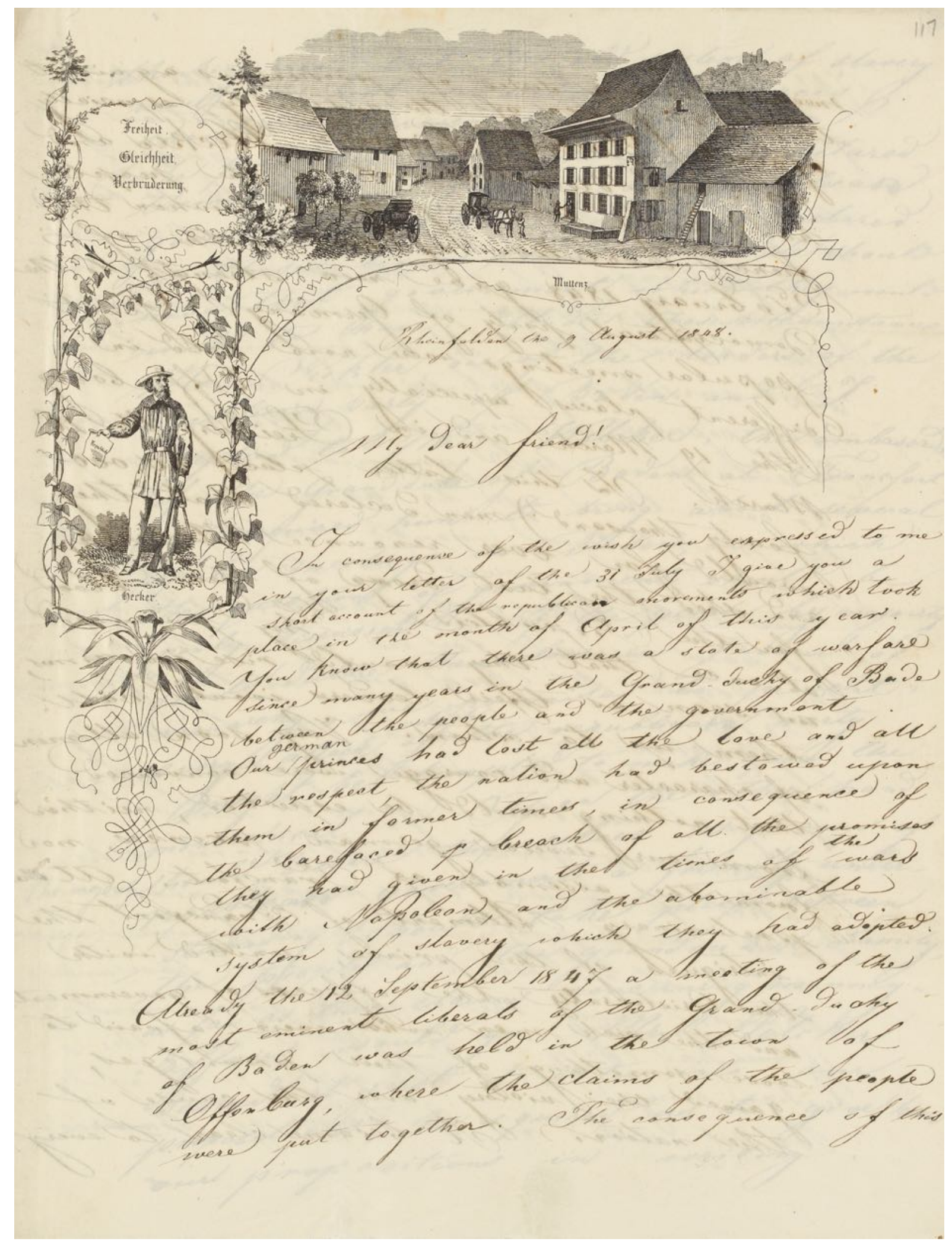

Fig. 6. Struve to Combe, 9 August 1848, MS7297 f.117, Combe Papers, National Library of Scotland, UK. 
revolution. Like the slave plantation or the eighteenth-century gaol, revolution provided no check on man's animal nature. He explained to Struve:

I desire a moral freedom, in which the selfish animal propensities shall be restrained, \& the higher faculties predominate. There must be a power capable of restraining \& directing the propensities, somewhere.

A stable society could only be achieved through 'a long apprenticeship to freedom under a representative government, with a monarchical head' ${ }^{181}$ In short, the kind of social relations already in operation in Britain. On receiving Combe's reply, Struve acknowledged that little could be said to change his mind. He simply expressed his wish that, whatever their political differences, the two phrenologists might remain on good terms, writing 'I hope that our friendship is still the same and that the storm which blew around us has not weakened its strength' ${ }^{182}$ This was Struve's final letter to Combe. They never spoke again.

\footnotetext{
${ }^{181}$ Combe to Struve, 31 July 1848, MS7391, f. 496, Combe Papers.

182 Struve to Combe, 30 Aug. 1849, MS7304, f. 15, Combe Papers.
} 